\title{
Stratospheric impact on tropospheric ozone variability and trends: 1990-2009
}

\author{
P. G. Hess ${ }^{1}$ and R. Zbinden ${ }^{2}$ \\ ${ }^{1}$ Cornell University, Department of Biological and Environmental Engineering, Ithaca NY, USA \\ ${ }^{2}$ Laboratoire d'Aérologie, UMR5560, CNRS et Université de Toulouse, Toulouse, France \\ Correspondence to: P. G. Hess (pgh25@cornell.edu) \\ Received: 22 June 2011 - Published in Atmos. Chem. Phys. Discuss.: 11 August 2011 \\ Revised: 24 November 2012 - Accepted: 13 December 2012 - Published: 18 January 2013
}

\begin{abstract}
The influence of stratospheric ozone on the interannual variability and trends in tropospheric ozone is evaluated between 30 and $90^{\circ} \mathrm{N}$ from 1990-2009 using ozone measurements and a global chemical transport model, the Community Atmospheric Model with chemistry (CAMchem). Long-term measurements from ozonesondes, at 150 and $500 \mathrm{hPa}$, and the Measurements of OZone and water vapour by in-service Airbus aircraft programme (MOZAIC), at $500 \mathrm{hPa}$, are analyzed over Japan, Canada, the Eastern US and Northern and Central Europe. The measurements generally emphasize northern latitudes, although the simulation suggests that measurements over the Canadian, Northern and Central European regions are representative of the large-scale interannual ozone variability from 30 to $90^{\circ} \mathrm{N}$ at $500 \mathrm{hPa}$. CAM-chem is run with input meteorology from the National Center for Environmental Prediction; a tagging methodology is used to identify the stratospheric contribution to tropospheric ozone concentrations. A variant of the synthetic ozone tracer (synoz) is used to represent stratospheric ozone. Both the model and measurements indicate that on large spatial scales stratospheric interannual ozone variability drives significant tropospheric variability at $500 \mathrm{hPa}$ and the surface. In particular, the simulation and the measurements suggest large stratospheric influence at the surface sites of Mace Head (Ireland) and Jungfraujoch (Switzerland) as well as many $500 \mathrm{hPa}$ measurement locations. Both the measurements and simulation suggest the stratosphere has contributed to tropospheric ozone trends. In many locations between $30-90^{\circ} \mathrm{N} 500 \mathrm{hPa}$ ozone significantly increased from 1990-2000, but has leveled off since (from 2000-2009). The simulated global ozone budget suggests global stratosphere-troposphere exchange increased in
\end{abstract}

1998-1999 in association with a global ozone anomaly. Discrepancies between the simulated and measured ozone budget include a large underestimation of measured ozone variability and discrepancies in long-term stratospheric ozone trends. This suggests the need for more sophisticated simulations including better representations of stratospheric chemistry and circulation.

\section{Introduction}

Tropospheric ozone is photochemically produced in situ from ozone precursor emissions or transported from the stratosphere. Tropospheric ozone impacts air quality and human health (Bell et al., 2004), atmospheric radiative forcing (Forster and Shine, 1997), and ecosystem productivity (UNEP, 2006) with resulting impacts on food (Chameides et al., 1994; Van Dingenen et al., 2009) and climate (Sitch et al., 2007). It also modifies the "oxidizing capacity" of the troposphere, impacting the lifetime and radiative forcing of methane (Fiore et al., 2002). Using conservative ozonemortality epidemiologic relationships (Bell et al., 2004), even one ppbv of ozone, currently approximately $20 \%$ of the surface ozone attributed to Stratosphere-Troposphere Exchange (STE) in the Northern Hemisphere (NH) mid- and high latitudes (Hess and Lamarque, 2007) may have relatively large consequences on human health (West et al., 2007).

Early semi-quantitative near-surface ozone measurements at the end of the 19th century (Volz and Kley, 1988; Marenco et al., 1994) suggest that ozone has increased 3-4 fold since the preindustrial period. Model simulations (Forster et al., 
2007) have been able to qualitatively capture much of this remarkable ozone increase, an increase driven by the increased emissions of ozone precursors associated with industrialization. However, an explanation for the interannual variability and trends in tropospheric ozone over the last few decades has proven more elusive despite the regulatory need to establish clear links between changes in tropospheric ozone and changes in precursor emissions and climate. Currently, ozone precursor emissions are increasing in some regions of the globe (e.g., over Asia) while decreasing in other locations (e.g., over Europe and the US) (Cooper et al., 2010). In the past two decades positive ozone trends have been found in many N.H. locations both representative of the free troposphere (Jaffe et al., 2003; Parrish et al., 2004; Tarasick et al., 2005; Zbinden et al., 2006; Thouret et al., 2006; Ordoñez et al., 2007; Cooper et al., 2010; Logan et al., 2012) as well as in the boundary layer with implications for air quality (Jaffe et al., 2003; Parrish et al., 2004; Simmonds et al., 2004; Carslaw, 2005; Derwent et al., 2007; Jaffe and Ray, 2007; Parrish et al., 2009; Wilson et al., 2012). In other locations ozone decreases have been reported (Oltmans et al., 2006; Lelieveld et al., 2004; Wilson et al., 2012). Over the west coast of the US large positive ozone trends in the mid-troposphere $\left(0.63 \pm 0.34 \mathrm{ppbv} \mathrm{yr}^{-1}\right)$ during April-May have been qualitatively associated with increased Asian emissions of ozone, although the magnitude of the trend is not generally consistent with that expected from model simulations (Cooper et al., 2010). Over rural European surface sites ozone trends have been on the average positive between 1996 and 2005, despite the overall decrease in European emissions (Wilson et al., 2012). The analysis by Logan et al. (2012) shows free tropospheric ozone increased over Central Europe throughout most of the 1990s, but has since decreased in the 2000s, with a significant decrease only during the summer months. At Mace Head, a site on the west coast of Ireland and exposed to incoming air off the Atlantic, baseline ozone trends filtered for background air have been large and positive between 1987 and $2003\left(0.49 \pm 0.19 \mathrm{ppbv} \mathrm{yr}^{-1}\right)$, although the trends appear to have leveled off in recent years (Derwent et al., 2007; Simmonds et al., 2004; Carslaw, 2005). Trends in emissions have not been able to qualitatively explain the ozone trends at Mace Head measurement site (Fiore et al., 2009) nor more generally within Europe as a whole (Logan et al., 2012). Zbinden et al. (2006) and Thouret et al. (2006) have analyzed trends in the tropospheric ozone column and upper tropospheric/lower stratospheric ozone of $1 \% \mathrm{yr}^{-1}$ from Measurements of OZone and water vapour by in-service Airbus aircraft programme (MOZAIC) during the late 20th and early 21 st century. These trends extend over three continents suggesting a common source of variability.

The difficulty in interpreting ozone trends is in part due to the fact that the ozone variability results from complex and mutually dependent interactions between meteorology, ozone photochemistry, and STE. Here we focus on the im- portance of STE in impacting interannual tropospheric ozone variability and trends. On local and regional scales previous work has found vertical correlations between lower stratospheric and tropospheric ozone. These correlations suggest the stratosphere exerts a considerable influence on tropospheric ozone concentrations: Tarasick et al. (2005) found significant interannual vertical correlations throughout much of the troposphere and lower stratosphere for the Canadian ozonesonde measurements network; Terao et al. (2008) found regionally specific vertical stratosphere-troposphere correlations both in ozonesonde data and in a model simulation, with the highest correlations during winter-spring; Thouret et al. (2006) found correlated ozone anomalies in the lower stratosphere and upper troposphere from MOZAIC; Ordoñez et al. (2007) found a high correlation between ozone measured at high alpine sites over Europe and lower stratospheric ozone at nearby ozonesonde stations, again with the largest correlations during the winter-spring period. Hsu and Prather (2009) show considerable interannual variability in STE, finding that the root mean square variability (from 2001-2005) is on the order of $10 \%$ of the overall STE. A number of modeling studies have also noted an association between El Nino Southern Oscillation (Zeng and Pyle, 2005; Voulgarakis et al., 2011) and the Arctic Oscillation (Hess and Lamarque, 2007) with STE.

In a comparison of future ozone predictions in $10 \mathrm{chem}-$ istry climate models (Stevenson et al., 2006) the net tropospheric ozone response is determined by the balance between increases in water vapor decreasing the concentration of ozone and the increase in STE increasing the concentration of ozone. Climate models almost universally predict an increase in the exchange of mass from the stratosphere to troposphere associated with climate warming (Butchart et al., 2006) with commensurate, although highly uncertain increases in the exchange of ozone between the stratosphere and troposphere (Stevenson et al., 2006; Zeng and Pyle, 2003; Collins et al., 2003; Shindell et al., 2006; Hegglin and Shepherd, 2009). Historic transient simulations have also indicated the stratospheric mass flux into the troposphere has increased during the latter part of the 20th century (Butchart et al., 2006) suggesting increased STE should already be occurring. Hegglin and Shepherd (2009) suggest that the stratospheric flux of ozone has been increasing at a nearly constant rate in the $\mathrm{NH}$ of approximately $2 \% /$ decade since 1970 . By 2100, Hegglin and Shepherd (2009) predict this alone will have increased ozone throughout much of the troposphere by $30 \%$ compared to 1970.

The analysis presented below indicates that on large spatial scales stratospheric interannual ozone variability drives significant tropospheric ozone variability. We primarily analyze the NH mid-latitudes and high-latitudes between 1990 and 2009 using analyzed ozone measurements from the stratosphere and troposphere in conjunction with a model simulation. We concentrate on ozone changes at $500 \mathrm{hPa}$, although we examine the surface record in a few locations. 
Section 2 describes our methodology and includes a description of the measurements and model used in this study. The data analysis of ozone trends and variability from the lower stratosphere to the surface is given in Sect. 3. Section 4 examines the model simulation including an evaluation against measurements and an analysis of the global and regional large-scale ozone budgets from 1990-2009. Discussion and conclusions are given in Sect. 5.

\section{Methodology}

The measured datasets, their analysis and details on the model simulations are given in this section.

\subsection{Data used and analysis procedure}

Measurements from ozonesondes are used to quantify the trend and variability in ozone from $500-150 \mathrm{hPa}$ between 30 and $90^{\circ} \mathrm{N}$. MOZAIC (Marenco et al., 1994a) measurements are analyzed only at $500 \mathrm{hPa}$ as these measurements do not extend to $150 \mathrm{hPa}$. MOZAIC data is provided by the ETHER (CNES/CNRS-INSU) web site (http://www.pole-ether.fr). A limited number of surface measurements are also analyzed, although surface measurements are not emphasized in this paper. Only measurement platforms with relatively frequent, consistent and long-term measurements were selected for analysis. In addition we required that the period from 1995 through 2005 be regularly sampled at any particular location. The datasets used are listed in Table 1 and described in more detail below.

The ozonesonde data was obtained from the World Ozone and Ultraviolet Radiation Data Centre (WOUDC). Two types of ozonesonde are used: the Electrochemical Concentration Cell (ECC) and the Brewer Mast (BM) bubbler. Both Payerne and Uccle switched from BM to ECC during the analyzed period. A number of studies have addressed how to harmonize the transition between $\mathrm{BM}$ and ECC ozonesonde measurements (see Stübi et al., 2008). We note Stübi et al. (2008) could not identify a significant discontinuity in ozone during the switch between ozonesonde types at Payerne; at Uccle De Backer et al. (1988) find the proper correction method renders the difference between the two measurement types insignificant. However, to be safe we elected to rely on only one of these two techniques for our analysis. At Payerne we only analyze the record prior to the switch from BM to ECC sondes in 2002. The ozone record at Uccle is not included as the ozonesonde switched type in 1997, within the middle of our base analysis period (1995-2005) and immediately prior to the large changes in analyzed ozone (see Fig. 3). Most ozonesonde profiles are modified by a correction factor (CF) to account for discrepancies between the ozonesonde measurements and measured total ozone. However, the use of a correction factor is controversial within the troposphere (SPARC, 1988). As in Logan $(1994,1999)$ the CF for each sonde profile is used to provide a filter for the quality of the data: to include a particular sounding in our analysis the correction factor had to be in the range $0.8-1.2$ for ECC and KC sondes and $0.9-1.35$ for BM sondes. Sampling frequency for the ozonesondes was never more than 16 per month over any particular site. Detailed discussion on ozonesonde measurements is given in SPARC (1988). Seventeen ozonesonde sites were selected for our data analysis (Table 1).

In addition to the ozonesonde measurements we analyze three regional clusters of vertical ozone profiles sampled at $500 \mathrm{hPa}$ during aircraft take-off and landing, measurements taken from the MOZAIC programme. The selection of MOZAIC measurements was determined so as to include the most visited regions and to have wide longitudinal coverage. Here the clusters combine the time-sorted ozone profiles over Frankfurt and Munich for the European region (15712 profiles from August 1994 to December 2008 with between 20 and 164 profiles/month); the Tokyo, Osaka and Nagoya profiles for the Asian region (3094 profiles from October 1994 to October 2006 with up to 53 profiles/month) and the New York, Boston and Washington profiles for the North American region (5052 profiles from August 1994 to August 2007 with up to 78 profiles/month) (Table 1). In most cases two profiles are taken per day. Clustering of MOZAIC airports, necessary to provide a continuous time-series and robust sampling frequency, is validated by the similarities in the seasonal cycle and concentrations between the overall cluster and the profiles over the individual airports. The MOZAIC profiles in 2005-2007 are rather infrequent over the Eastern US (there are 28 months where the sampling rate is less than 16 profiles/month). Over Japan there are 41 months where the sampling is less than 16 profiles/month. At the surface we examined ozone measurements at four sites on three different continents (Table 1). The ozone record at these sites is taken from the WMO Global Atmospheric Watch World Data Center for Greenhouse Gases and is based on hourly data.

To analyze the measurements at a particular location we use the following procedure. (i) The ozone measurements were binned by month to create a monthly averaged ozone concentration at each site and for each altitude for the base period from 1995-2005. This period provides an approximate five-year buffer on each side of the large measured ozone increases during 1998-1999. It also coincides with our record of ozone data from the MOZAIC programme. (ii) Monthly ozone deviations were calculated at each site and altitude by subtracting the monthly averaged ozone for a particular month and year from the multi-year (1995-2005) monthly average. (iii) Smoothed ozone deviations at each site and altitude are obtained by taking a running mean of the monthly deviations at each measurement site. In the following text S12MD (Smoothed 12 Month Deviations) will refer to the 12 month running mean of monthly ozone deviations. The 12-month running mean is used to highlight deviations in annually averaged ozone; the monthly deviations 
Table 1. Measurements included in our analysis.

\begin{tabular}{|c|c|c|c|c|c|c|c|c|}
\hline Region $^{1}$ & Station & Platform $^{2}$ & Lon. & Lat. & $\begin{array}{l}\text { Site } \\
\text { elevation }\end{array}$ & Period $^{3}$ & Validity $^{4}$ & $\begin{array}{l}\text { Number of } \\
\text { Observations } 5\end{array}$ \\
\hline \multirow{7}{*}{ Canada $^{6,7}$} & Alert & Ozonesonde & $62^{\circ} \mathrm{W}$ & $82^{\circ} \mathrm{N}$ & NA & 1989-2008 & 150,500 & 1072 \\
\hline & Churchill & Ozonesonde & $94^{\circ} \mathrm{W}$ & $59^{\circ} \mathrm{N}$ & NA & 1989-2008 & 150,500 & 862 \\
\hline & Edmonton & Ozonesonde & $114^{\circ} \mathrm{W}$ & $54^{\circ} \mathrm{N}$ & NA & 1990-2008 & 150,500 & 911 \\
\hline & Eureka & Ozonesonde & $85^{\circ} \mathrm{W}$ & $80^{\circ} \mathrm{N}$ & NA & $1992-2008$ & 150,500 & 1127 \\
\hline & Goose Bay & Ozonesonde & $60^{\circ} \mathrm{W}$ & $53^{\circ} \mathrm{N}$ & NA & 1989-2008 & 150,500 & 965 \\
\hline & Resolute & Ozonesonde & $95^{\circ} \mathrm{W}$ & $75^{\circ} \mathrm{N}$ & NA & 1989-2008 & 150,500 & 770 \\
\hline & Egbert & Surface & $80^{\circ} \mathrm{W}$ & $44^{\circ} \mathrm{N}$ & $253 \mathrm{~m}$ & 1990-2003 & Surface & 119309 \\
\hline \multirow{5}{*}{ Japan } & Kagoshima & Ozonesonde & $131^{\circ} \mathrm{E}$ & $32^{\circ} \mathrm{N}$ & NA & 1989-2005 & 150,500 & 599 \\
\hline & Sapporo & Ozonesonde & $141^{\circ} \mathrm{E}$ & $43^{\circ} \mathrm{N}$ & NA & 1989-2008 & 150,500 & 785 \\
\hline & Tateno & Ozonesonde & $140^{\circ} \mathrm{E}$ & $36^{\circ} \mathrm{N}$ & NA & 1989-2008 & 150,500 & 1029 \\
\hline & MOZAIC $^{8}$ & Aircraft & NA & NA & NA & 1994-2006 & 500 & 3094 \\
\hline & Ryori & Surface & $142^{\circ} \mathrm{E}$ & $39^{\circ} \mathrm{N}$ & $260 \mathrm{~m}$ & 1990-2008 & Surface & 158983 \\
\hline \multirow{2}{*}{$\begin{array}{l}\text { Eastern US } \\
\text { (USEAST) }\end{array}$} & Wallops & Ozonesonde & $76^{\circ} \mathrm{W}$ & $38^{\circ} \mathrm{N}$ & NA & 1994-2006 & 150,500 & 832 \\
\hline & MOZAIC $^{9}$ & Aircraft & NA & NA & NA & 1994-2006 & 500 & 5050 \\
\hline \multirow{3}{*}{$\begin{array}{l}\text { Northern Europe } 6,7 \\
\text { (NEUROPE) }\end{array}$} & Ny Alesund & Ozonesonde & $12^{\circ} \mathrm{E}$ & $79^{\circ} \mathrm{N}$ & NA & 1990-2006 & 150,500 & 1713 \\
\hline & Scoresbysund & Ozonesonde & $22^{\circ} \mathrm{W}$ & $70^{\circ} \mathrm{N}$ & NA & $1993-2003$ & 150,500 & 585 \\
\hline & Sodankyla & Ozonesonde & $26^{\circ} \mathrm{W}$ & $67^{\circ} \mathrm{N}$ & NA & 1989-2006 & 150,500 & 1372 \\
\hline \multirow{8}{*}{$\begin{array}{l}\text { Central Europe }^{7} \\
\text { (CEUROPE) }\end{array}$} & Debilt & Ozonesonde & $5^{\circ} \mathrm{E}$ & $52^{\circ} \mathrm{N}$ & NA & $1992-2008$ & 150,500 & 860 \\
\hline & Hohenpeissenberg & Ozonesonde & $11^{\circ} \mathrm{E}$ & $48^{\circ} \mathrm{N}$ & NA & 1989-2008 & 150,500 & 2432 \\
\hline & Legionowo & Ozonesonde & $21^{\circ} \mathrm{E}$ & $52^{\circ} \mathrm{N}$ & NA & 1993-2008 & 150,500 & 937 \\
\hline & Lindenberg & Ozonesonde & $14^{\circ} \mathrm{E}$ & $52^{\circ} \mathrm{N}$ & NA & 1992-2008 & 150,500 & 906 \\
\hline & Payerne & Ozonesonde & $8^{\circ} \mathrm{E}$ & $47^{\circ} \mathrm{N}$ & NA & 1989-2002 & 150,500 & 1809 \\
\hline & MOZAIC $^{10}$ & Aircraft & NA & NA & NA & 1994-2008 & 500 & 15712 \\
\hline & Jungfraujoch & Surface & $8^{\circ} \mathrm{E}$ & $47^{\circ} \mathrm{N}$ & $3580 \mathrm{~m}$ & 1989-2008 & Surface & 163694 \\
\hline & Mace Head ${ }^{11}$ & Surface & $10^{\circ} \mathrm{E}$ & $53^{\circ} \mathrm{N}$ & $10 \mathrm{~m}$ & $1989-2007^{12}$ & Surface & $144853^{13}$ \\
\hline
\end{tabular}

\footnotetext{
${ }^{1}$ The region the measurement is classified into. ${ }^{2}$ Platform for the selected ozone measurements. ${ }^{3}$ Beginning and ending date for measurement period included in this study. We include data from 1989 so as to have a record of annually averaged ozone on 1 January 1990 when we being our analysis. ${ }^{4}$ Location of analyzed ozone measurements (150 hPa, $500 \mathrm{hPa}$ or at the surface). ${ }^{5}$ The total number of surface measurements, flights or ozonesondes launched within the period. In some cases a valid measurement was not available on a particular pressure level. ${ }^{6}$ Regionally consistent ozone record constructed at $500 \mathrm{hPa}$ for this region. ${ }^{7}$ Regionally consistent ozone record constructed at $150 \mathrm{hPa}$ for this region. ${ }^{8}$ Time sorted MOZAIC ozone profiles over Tokyo, Osaka and Nagoya (JAPAN). ${ }^{9}$ Time sorted MOZAIC profiles for New York, Boston and Washington (USEAST).

10 Time sorted MOZAIC profiles for Frankfurt and Munich (CEUROPE). ${ }^{11}$ At the Mace Head site we use both baseline data where the ozone record has been filtered for incoming air over the Atlantic and the unfiltered data. ${ }^{12}$ Our record of the baseline Mace Head measurements ended in $2006 .{ }^{13}$ Number of measurements after 1990. Prior to 1990 only monthly averaged measurement data was available to us.
}

can be quite noisy. When 3 or more months are missing from the 12 month running mean, the mean is not computed. Seasonal ozone deviations are also analyzed and are obtained by smoothing the monthly ozone deviations over 3 or 6 months.

Next we construct regional records of ozone variability and trends. We combine the records regionally to isolate the larger-scale interannual variability over a larger geographical region and to increase the sampling frequency. The sampling frequency at any one station may be too infrequent to detect ozone trends (Jaffe and Ray, 2007). The simulations discussed below (Sect. 4) suggest that examining the regional tropospheric signal is more representative of the impact of the stratosphere than the signal at any individual measurement site. The regions are selected based on the geographic location of the measurement sites, coherency of the measurements between the different measurement sites (see Tables S1 and S2) and the number of measurements. We ex- amined the ozone signal for five different regions: Canada, Japan, the Eastern US, and Northern, and Central Europe (see Table 1). All these regions have at least two independent measurement sites. We consider the ozone record to be regionally consistent when the measurements at the different sites within the region have a high degree of correlation (see Tables S1 and S2). In each region we only analyzed the ozone record during those years for which we could determine the annually averaged concentration at two or more measurement sites. We excluded the measurement sites at Boulder and Madrid from our analysis, as an independent long-term measurement site does not exist in the vicinity these locations.

More specifically, regional records of ozone variability were constructed using the following procedure. (i) First, we normalized the smoothed ozone record at each site within the region dividing the S12MD record of ozone anomalies 
by its standard deviation. The trend is not removed prior to normalization. We refer to the normalized S12MD ozone signal as NS12MD ozone. (ii) Second we constructed a normalized regional ozone record by averaging the resulting normalized records from all the sites within a region. Averaging the NS12MD records allows us to construct a regional signal where the variability at each station is given equal weight. Simply averaging the ozone deviations themselves is likely to weight the overall regional record towards those stations with greater average ozone concentrations. Note that the adapted method may give less weight to those stations with larger trends.

Regional ozone trends (in ppbv $\mathrm{yr}^{-1}$ ) cannot be analyzed using the normalized signal. The regional trends are calculated over two periods: from 1990-2000, and from 20002009. These periods yield distinctly different trends at many sites. Within a particular region regional ozone trends are calculated by averaging the trends of the ozone record derived separately at each measurement site. In the case a site has an incomplete measurement record, we weight the trends calculated at that site by the fraction of measured months within each period. Trends are only calculated for those sites with data at the beginning and end of the period of interest.

\subsection{Chemical transport model}

The three-dimension chemistry transport model used in these simulations is the Community Atmosphere Model with chemistry (CAM-chem) (see Lamarque et al., 2012), in which chemistry from the Model of Ozone and Related Tracers version 4 (MOZART-4) (Emmons et al., 2010) has been imported into the Community Atmosphere Model (Collins et al., 2006). In these simulations CAM-chem is driven by the reanalysis meteorology from the National Center for Environmental Prediction/National Center for Atmospheric Research (NCEP/NCAR) (Kalnay et al., 1996). Except for lightning emissions, the tropospheric emissions of all species in these simulations (including biogenic emissions and soil $\mathrm{NO}_{\mathrm{x}}$ ) have no interannual variation. The lightning source of NO is computed internally within the model from the diagnosed convective clouds using a parameterization based on Price and Rind (1992) (see Emmons et al., 2010 for details). Emissions are largely based on the POET emission inventory and are reported in Fiore et al. (2009). The methane concentration at the lower boundary is specified with no interannual variation. The model simulation has been spun up for two years prior to 1990 .

Recently CAM-chem has been thoroughly described and evaluated (Lamarque et al., 2012) using Modern Era Retrospective-Analysis for Reasearch (MERRA) and Goddard Earth Observation System version 5 (GEOS-5) offline meteorological fields. Depending on the meteorology used the $500 \mathrm{hPa}$ Northern mid-latitude ozone bias over selected ozonesonde sites generally ranges between a few ppbv to a little over $10 \mathrm{ppbv}$ with a seasonal measurement-observation correlation near 0.9. Results from CAM-chem driven by NCEP reanalysis fields have been used and evaluated in the international assessment of source-receptor relationships for Hemispheric Transport of Air Pollution (HTAP) (Fiore et al., 2009; UNCEC, 2007; Sanderson et al., 2008; Shindell et al., 2008; Anenberg et al., 2009; Reidmiller et al., 2009). In particular Jonson et al. (2010) compared simulated ozone in CAM-chem against ozonesonde measurements.

The version of CAM-chem used in these simulations has no explicit representation of stratospheric ozone chemistry and rather coarse stratospheric resolution. To specify the stratospheric ozone concentrations we modify the parameterization for synoz (synthetic ozone tracer) (McLinden et al., 2000). As specified in McLinden et al. (2000) synoz is a passive ozone-like tracer released into the simulated equatorial stratospheric ozone production region $(70-10 \mathrm{hPa}$ and $30^{\circ} \mathrm{S}-30^{\circ} \mathrm{N}$ ) at a rate equivalent to the stratospheric to tropospheric flux of ozone; it is destroyed in the lower troposphere with an e-folding timescale of 2-days. Above the tropopause the concentration of simulated ozone is set equal to that of synoz. This ensures the stratosphere to troposphere flux of ozone and synoz are the same. The synoz parameterization has been used in the GEOS-chem model (Bey et al., 2001) as well as in the CAM-chem simulations for HTAP (see citations above) and the MOZART-2 simulations of the Arctic Oscillation (AO) (Hess and Lamarque, 2007).

The synoz parameterization corrects for the excessive STE frequently found when driving models using assimilated wind fields and specified stratospheric ozone fields. The cross-tropopause flux of synoz is not particularly sensitive to details of the stratospheric circulation. This can be seen by the following argument. As the stratospheric mean meridional circulation increases an airmass spends less time in the region where the synoz source is applied. This implies that as the circulation rate increases the concentration of synoz within the equatorial source region (approximately equal to the amount of time that an airmass resides within the equatorial source region) decreases. Conversely, if the circulation rate decreases the concentration of synoz within the equatorial source region increases. Thus, since the flux of synoz transported out of the equatorial source region is proportional to the strength of the mean meridional circulation times the concentration of synoz, and these two quantities vary inversely, the flux of synoz is relatively insensitive to changes in circulation strength. At steady-state, when the loss of synoz is in balance with its source the cross-tropopause flux of ozone and synoz are equal to the specified production rate of synoz (specified to be equivalent to the stratospheric to tropospheric flux of ozone).

In this paper we have modified the parameterization of synoz so as to: (i) keep the stratosphere-to-troposphere flux of ozone roughly constrained, (ii) allow the STE of ozone to be sensitive to interannual changes in the stratospheric circulation. To do this we specify the concentration of a synoz-like tracer (instead of its production rate) within the equatorial 
stratospheric ozone production region. We will denote this tracer as synoz*. Because the concentration of synoz* is specified (and not its source strength) the flux of synoz* out of the equatorial source region will be sensitive to changes in the strength of the mean-meridional circulation. Except for this change, the methodology used here is the same as that used in specifying the synoz tracer in its original formulation. In particular, the parameterization used in this paper was implemented as follows. (1) First we equilibrate the concentration of synoz (as specified in McLinden et al., 2000) by running CAM-chem on the order of $10 \mathrm{yr}$. In the equilibration run the source of synoz is set to $500 \mathrm{Tg} \mathrm{yr}^{-1}$. (2) The equilibrated concentration of synoz (between $30^{\circ} \mathrm{S}-30^{\circ} \mathrm{N}$ and 10 and $70 \mathrm{hPa}$ ) is saved during a test-year to produce an annual record of synoz* concentrations in the defined equatorial production region. (3) We check that specifying the flux of synoz or the concentration of synoz* produce the same result during the given test year. We also check that the distribution of synoz* does not drift interannually due to a poor initialization. Details of this latter test can be found in the Supplement (see Fig. S1). Both checks show the implementation of synoz* is indeed correct. This parameterization only captures the variation in STE due to variations in circulation, not due to changes in stratospheric chemistry. The concentration of synoz* is specified to be the same each year. This has the advantage of isolating the impact of changes in circulation on STE. Voulgarakis et al. (2011) finds that the variability in stratospheric ozone itself is almost negligible in accounting for changes in simulated post-El Niño increases of ozone STE; the changes are almost completely due to changes in the circulation.

The seasonal cycle of simulated stratospheric ozone at $150 \mathrm{hPa}$ is compared against measurements in Figs. S2-S4 (also see Fig. 5 discussed below). At this altitude the concentration of ozone is equal to that of synoz*. As expected simulated ozone underestimates the measured ozone in the stratosphere, but by design the consequent STE of ozone is approximately correct. The amplitude of the simulated seasonal cycle of ozone at $150 \mathrm{hPa}$ also underestimates the measured seasonal cycle. The simulated maximum ozone concentration at $150 \mathrm{hPa}$ tends to occur one to two months after the measured March-April peak. The timing of the measured October $150 \mathrm{hPa}$ ozone minimum is better simulated.

The tropospheric ozone distribution is compared against measurements in the Supplement Figs. S2-S6 (also see Tables 2 and 3 and Figs. 5-7 discussed below). The simulated ozone slightly overestimates ozone throughout most of the troposphere (Figs. S5-S6), but significantly overestimates ozone at the surface (except over Northern Europe). This surface bias is common to many global model simulations (Pozzoli et al., 2011; Ellingsen et al., 2008) and is evident in CAM-chem simulations using a variety of meteorological input fields (Lamarque et al., 2012) and alternative methodologies for specifying the stratospheric ozone concentrations. Vertical profiles of ozone in these simulations are very similar to those given by Hess and Lamarque (2007) in the MOZART-2 chemical transport model using the standard synoz parameterization (see Figs. S5 and S6). In the latter paper MOZART-2 is shown to simulate the interannual ozone variability associated with the AO in February-March, which in many locations is driven by the interannual variability in STE. The amplitude of the tropospheric seasonal cycle in ozone over the Canadian, Northern European and Eastern US regions is less than observed. While the overall simulated mid-tropospheric ozone bias is small (Table 2, Figs. S5-S6) the simulation underestimates the measured ozone concentrations during summer and overestimates them during winter. Consistent with the simulation at $150 \mathrm{hPa}$, the timing of the simulated $500 \mathrm{hPa}$ ozone maximum is generally one month to two months too late (two months over the Eastern US), although the timing of the seasonal ozone mimimum agrees well with the measurements.

A tagging method is used to tag and track all tropospheric odd nitrogen as the nitrogen is emitted (including the emissions of $\mathrm{NO}_{\mathrm{x}}$ from soils and lightning) and subsequently physically transported and chemically modified (Hess and Lamarque, 2007; Emmons et al., 2012). Tropospheric photochemical ozone is defined as that portion of ozone produced through the tropospheric photochemical reactions involving the tagged nitrogen species. We refer to tropospheric photochemical ozone as $\mathrm{O}_{3 \mathrm{NO}_{\mathrm{x}}}$. Tropospheric photochemical ozone $\left(\mathrm{O}_{3 \mathrm{NO}_{\mathrm{x}}}\right)$ is destroyed in the troposphere through the simulated photochemistry and in the stratosphere with a fixed timescale of 10 days. Previous studies (e.g., Dahlmann et al., 2011; Grewe, 2004; Lelieveld and Dentener, 2000) have also calculated ozone concentrations through the use of tagging methodologies. Emmons et al. (2012) shows that the tagged ozone concentration $\left(\mathrm{O}_{3 \mathrm{NO}_{\mathrm{X}}}\right)$ is almost identical to the untagged ozone concentration $\left(\mathrm{O}_{3}\right)$ when all tropospheric sources of $\mathrm{NO}_{\mathrm{x}}$ are tagged and stratospheric sources of ozone and odd nitrogen are turned off. By tagging tropospheric photochemical ozone we explicitly quantify the portion of ozone in the troposphere that is not due to $\mathrm{NO}_{\mathrm{x}}$ catalyzed reactions: it is simply the difference between the total simulated ozone and $\mathrm{O}_{3 \mathrm{NO}_{\mathrm{x}}}$. We refer to the difference between $\mathrm{O}_{3}$ and $\mathrm{O}_{3 \mathrm{NO}_{\mathrm{x}}}$ as stratospheric ozone $\mathrm{O}_{3 \mathrm{~S}}$, although a small fraction could have originated from tropospheric photochemical reactions that produce $\mathrm{O}_{3}$ without $\mathrm{NO}_{\mathrm{x}}$ mediated photochemistry. This method is fully linear, in the sense that ozone concentration ascribed to individual $\mathrm{NO}_{\mathrm{x}}$ sources adds to the total ozone concentration diagnosed from all the sources (Emmons et al., 2012). This methodology produces a significantly different and lower tropospheric distribution of stratospheric ozone (Hess and Lamarque, 2007) than studies using an ozone tracer set to the mixing ratio of ozone in the stratosphere and destroyed in the troposphere at the same rate as ozone (e.g., Roelofs and Lelieveld, 1997; Emmons et al., 2003). By simply turning off the stratospheric input of ozone Fusco and Logan (2003) simulated low surface concentrations of stratospheric ozone similar to those found in 
both this study and Hess and Lamarque (2007). Hess and Lamarque (2007) argue that the use of the tagged $\mathrm{NO}_{\mathrm{x}}$ to calculate stratospheric ozone offers a number of conceptual advantages over using a stratospheric ozone tracer.

\section{Ozone variability - the observational record from $30-90^{\circ} \mathrm{N}$}

In this section we examine the observed record of ozone variability from the lower stratosphere to the surface for the selected measurement sites (see Table 1) from $30-90^{\circ} \mathrm{N}$ between 1990 and 2009.

\subsection{Tropospheric ozone record}

The normalized smoothed monthly ozone deviations (NS12MD) at $500 \mathrm{hPa}$ for individual measurement sites within five different regions (see Table 1) are given in Figs. 1 and 2. Table S1 gives the correlation between the individual measurement sites. The individual measurement sites over the Canadian, Northern European, Japanese and Eastern US regions are generally significantly correlated while the the individual sites over Central Europe are generally not significantly correlated (Table S1). In particular, the correlation between the individual measurements for the Canadian and Northern European sites is generally highly significant (Table S1). As discussed in more detail below a number of features of the measured record are common to all regions.

The measured record over Central Europe (see Fig. 2) bears somewhat more discussion as the European measurement network is particularly dense, regularly and frequently sampled and subsequently often used to evaluate model simulations. The measurements at individual sites within Central Europe are generally positively correlated, but not significantly so (Table S1), and there are comparatively large differences in the ozone record between the different sites (Fig. 2). We have included one surface station, the Jungfraujoch, as a comparison in Fig. 2. While the pressure at Jungfraujoch site $(3580 \mathrm{~m})$ is somewhat higher than $500 \mathrm{hPa}$, the measurements at Jungfraujoch are highly correlated with the $500 \mathrm{hPa}$ MOZAIC measurements over Europe (correlation is 0.68). They are also significantly correlated with the ozonesonde record over the Northern Europe ozonesonde sites, the ozonesonde record over the Canadian sites and the MOZAIC measurements over the US (Table S1). The Jungfraujoch measurements are not significantly correlated with any of the Central European ozonesonde measurement stations during the period 1990-2009. The correlation between the European ozonesonde sites and the European MOZAIC cluster is generally low and frequently negative. Discussion of differences between alpine ozone measurements over Europe, MOZAIC measurements and ozonesonde measurements can be found in Jeannet et al. (2007) and Logan et al. (2012). Logan et al. (2012) shows that the datasets agree after 1998, but have

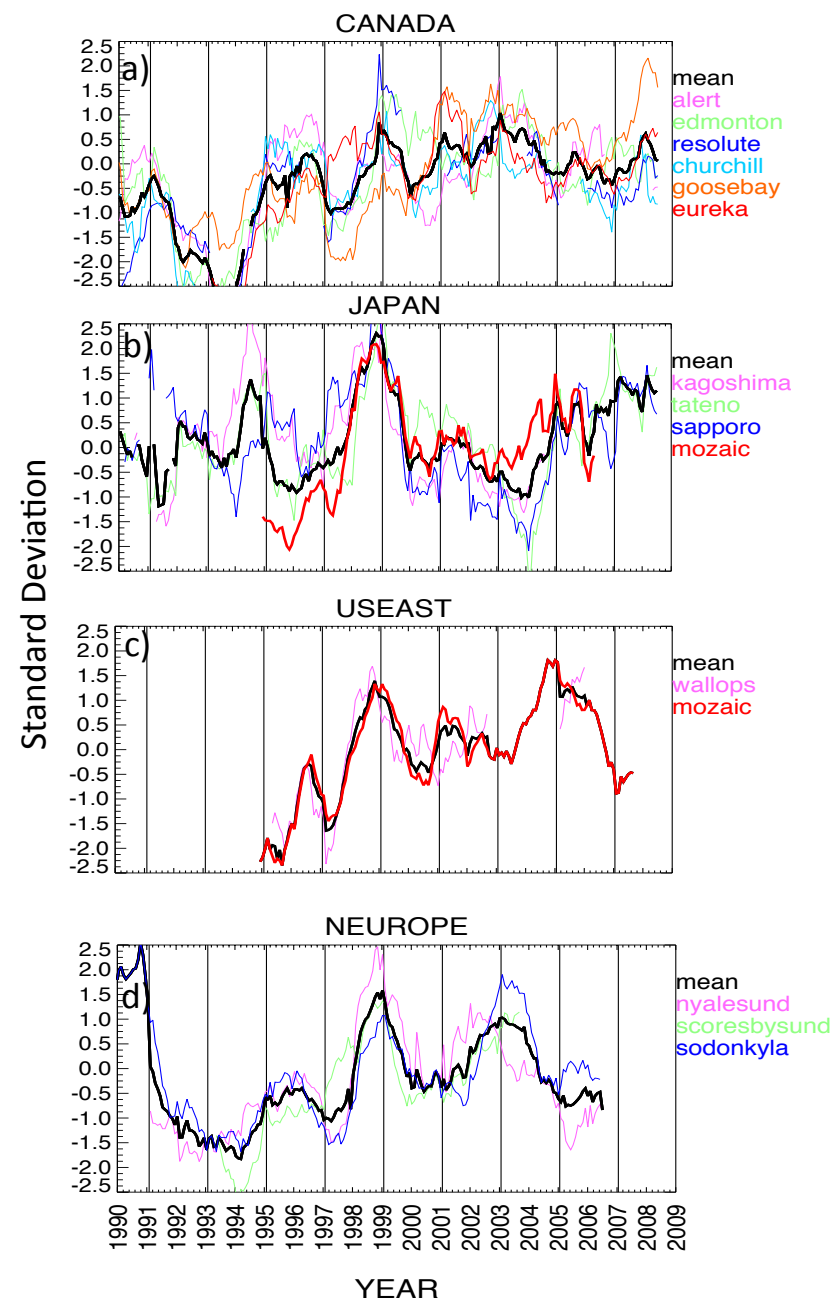

Fig. 1. Normalized 12-month running mean of $500 \mathrm{hPa}$ ozone measurement anomalies (NS12MD, see text) for the following regions: (a) Canada, (b) Japan, (c) US East and (d) Northern Europe. Measurements from each individual ozonesonde site and MOZAIC (thick red lines) are shown. At each measurement site the monthly ozone deviation from the 1995-2005 mean is smoothed using a 12 month running mean. The resulting record is then divided by its standard deviation. Thus ozone is plotted as its standard deviation from the mean. Over each region the NS12MD records from the individual sites are averaged (thick black line) when sufficient measurements are available for at least two measurement sites to report an annually averaged concentration.

substantial disagreements prior to that time. The central European ozonesonde sites and MOZAIC are all geographically close: the spatial differences between the measurement sites are unlikely to explain their differences (Schnadt Poberaj et al., 2009). Saunois et al. (2012) investigates the impact of sampling frequency on the ozone record, and includes an analysis of the MOZAIC record over Frankfurt.

Nevertheless, by simply averaging all the individual NS12MD ozonesonde and MOZAIC ozone records (Fig. 2) over Central Europe we find the regionally averaged record 


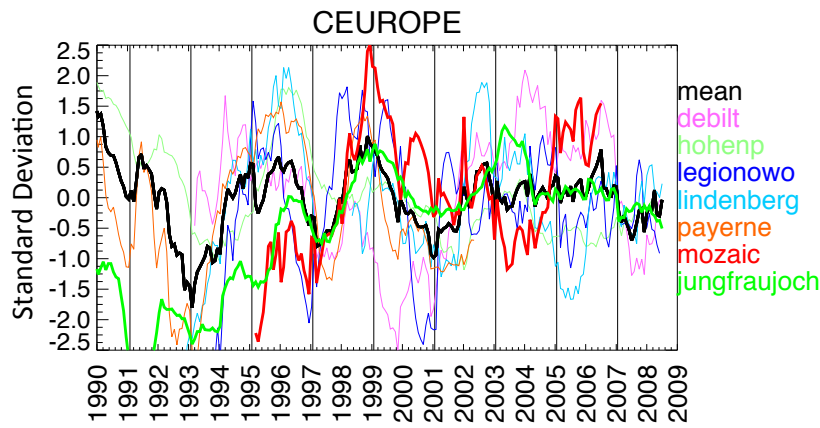

YEAR

Fig. 2. As in Fig.1 but for the Central European region at $500 \mathrm{hPa}$, with the exception that the surface measurements at Jungfraujoch ( $3580 \mathrm{~m}$, approximately $650 \mathrm{hPa}$ ) are shown for comparison. The Jungfraujoch and MOZAIC measurements are marked by thick lines.

is generally consistent with that found in other regions: there are ozone minima near 1993, 1997 and 2000, with an ozone maximum in 1999. An ozone maximum from 1994 into 1996 seems to occur in most of the station records during this period. However, while the MOZAIC and Jungfraujoch measurements suggest the amplitude of this maximum is less than that of the 1998-1999 event, many of the ozonesonde sites suggest this earlier peak is the stronger of the two (i.e., Payerne, Lindenberg, Hohenpeissenberg, De Bilt).

In each of the five regions examined we have constructed an averaged ozone record from the individual NS12MD ozone records within that region (Figs. 1-3). We further average the ozone record over Northern European, Eastern US and Canadian regional ozone records to produce our best guess of interannual variations in the large-scale ozone signal (Fig. 3a). We simply refer to the resulting averaged record as the average $500 \mathrm{hPa}$ ozone record. We exclude Central Europe from this average, as the station records within this region have limited correlation (Table S1) are not selfconsistent (see Fig. 2). We exclude Japan from this average as both the simulation and the measurements suggest the ozone variations over the Japanese stations are not well correlated with the other measurement sites (see Table S1 and Fig. 3a). This is perhaps not surprising as the Japanese ozonesondes are further south than the other regions examined and are impacted by the summertime monsoon (Zbinden et al., 2006) circulation.

The average $500 \mathrm{hPa}$ ozone record shows a pronounced ozone peak in 1998-1999, and minima in 2000 and 1993 (Fig. 3a). The record from the individual regions (Fig. 1a) shows a similar pattern, although the minima over Japan are not pronounced. Using MOZAIC-derived measurements of tropospheric ozone column Zbinden et al. (2006) also noted the 1998-1999 ozone anomaly extended to three continents. The ozone minimum from 1992-1994 in the average record is most pronounced over the Canadian stations. Oltmans et
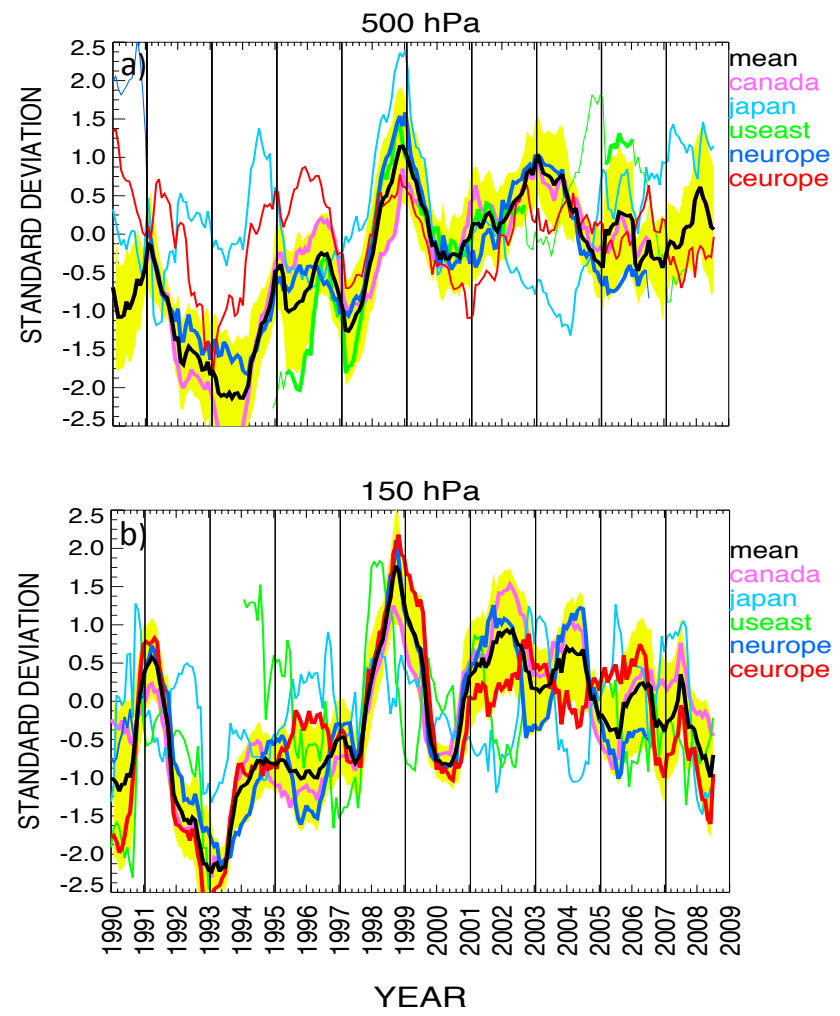

Fig. 3. Normalized 12-month running mean of regionally averaged ozone measurement anomalies (NS12MD) for (a) ozonesondes and MOZAIC measurements at $500 \mathrm{hPa}$, (b) ozonesonde measurements at $150 \mathrm{hPa}$. In each region the records from each measurement site are analyzed as in Fig. 1 and then averaged. Thick lines indicate the regions with consistent records (Canada, Northern Europe and Central Europe at $150 \mathrm{hPa}$; Canada, Northern Europe and the Eastern US at $500 \mathrm{hPa}$ ) and the times when at least two concurrent measurements are available within a given region. The thick black line gives the average ozone over those regions with consistent measurements. The width of the yellow shaded region gives two standard deviations of the individual records that comprise the overall averaged signal.

al. (1998) and Fusco and Logan (2003) relate this ozone minimum at high latitudes to the impact of Pinatubo.

The average $500 \mathrm{hPa}$ ozone record is constructed from sites that represent a relatively small fractional area of the troposphere from $30-90^{\circ} \mathrm{N}$ and has a high latitude bias. The individual stations comprising this record extend from $38^{\circ} \mathrm{N}$ (Wallops) to $82^{\circ} \mathrm{N}$ (Alert), and from $114^{\circ} \mathrm{W}$ (Edmonton) to $27^{\circ} \mathrm{E}$ (Sodankyla) (Table 1 ). The average measured $500 \mathrm{hPa}$ ozone record explains $39 \%$ of the variance of the regional $500 \mathrm{hPa}$ ozone record over the Eastern US, $45 \%$ of the variance over Northern Europe and $88 \%$ of the variance over Canada. To what extent does the constructed average $500 \mathrm{hPa}$ ozone record represent large-scale variations in $30-90^{\circ} \mathrm{N}$ ozone? From the analyzed measurements it is impossible to tell. However, simulated ozone (see Sect. 4) suggests that this 
average record is indeed representative of $30-90^{\circ} \mathrm{N}$ ozone variations.

\subsection{Stratospheric ozone record}

The $150 \mathrm{hPa}$ ozone signal averaged over each of the five regions is given in Fig. $3 \mathrm{~b}$ as analyzed from the ozonesonde measurements (the MOZAIC measurements do not extend to $150 \mathrm{hPa}$ ). At $150 \mathrm{hPa}$ the Canadian region (six sites), the Central European region (five sites), and the Northern European region (three sites) have regionally consistent ozone records. The six sites in Canada are positively correlated, with most of the correlations significant at the $95 \%$ level (Table S2); within the Central European and Northern European regions most of the sites are also highly correlated with each other (Table S2). We were not able to isolate a regionally consistent record over the Eastern US at $150 \mathrm{hPa}$ : only one ozonesonde measurement is available in that region, precluding us from being able to evaluate the consistency of the record. We were not able to isolate a consistent ozone signal in the lower stratosphere for the Japanese stations. The correlation amongst the three Japanese sites at $150 \mathrm{hPa}$ is small and insignificant (Table S2), although this is perhaps not surprising as these sites span a wide latitudinal range $\left(32-43^{\circ} \mathrm{N}\right)$. Increasing the altitude of the sampling, or examining the correlation only during the winter months did not increase the correlations amongst the Japanese sites.

We construct an average measured $150 \mathrm{hPa}$ ozone signal by averaging the NS12MD ozone records over regions with regionally consistent $150 \mathrm{hPa}$ signals: Canada, Central Europe and Northern Europe (Fig. 3b, solid black line). The average $150 \mathrm{hPa}$ signal explains between $79 \%$ (Central Europe) and $86 \%$ (Northern Europe and Canada) of the individual regional averages. The regional signal from Canada and Northern Europe in particular shows a very high degree of correlation from year to year. The signal from Central Europe, while showing the same large amplitude variability as the Canadian and Northern European signals deviates somewhat in the smaller amplitude variability. As with the average $500 \mathrm{hPa}$ ozone record, the average $150 \mathrm{hPa}$ record is constructed from measurements that only sample a relatively small fraction of the lower stratosphere (see Table 1) with a weight towards the northern latitudes.

The interannual variability in the lower stratospheric ozone record can be attributed to the interplay between stratospheric dynamics and photochemistry (Shepherd, 2008). With the exception of Japan the long timescale variability in all regions is similar with ozone concentrations from 2001-2009 uniformly higher than those prior to 1997. All regions, even those without regionally consistent records have an ozone maximum in 1998-1999 timeframe (Fig. 3b). An analysis of MOZAIC measurements in the upper tropospheric and lower stratospheric over Iceland, the Eastern US and Europe also clearly indicates a pronounced lower stratospheric positive ozone anomaly during 1998-1999 time-

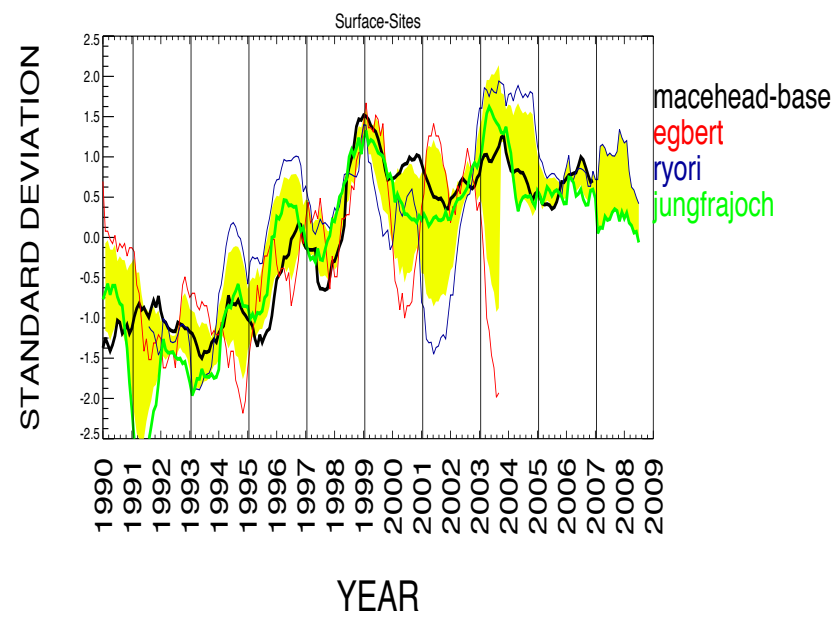

Fig. 4. Normalized 12-month running mean of the surface ozone measurement anomalies (NS12MD) at: Mace Head Ireland (10 m); Egbert Canada (253 m); Ryori, Japan (260 m), and the Jungfraujoch Switzerland $(3580 \mathrm{~m})$. The Mace Head data is shown filtered for clean air (Derwent et al., 2007). Records from each site are analyzed as in Fig. 1. The width of the yellow shaded region gives two standard deviations of the records about their overall mean.

frame (Thouret et al., 2006). The lower stratospheric ozone minimum at $150 \mathrm{hPa}$ in 1992 and 1993 (Fig. 3b) can be attributed, at least in part, to the Mt. Pinatubo eruption in June 1991 (WMO, 2003) although circulation anomalies may also have played a role (Hadjinicolaou et al., 1997).

\subsection{Surface ozone record}

It is outside the scope of this paper to make a thorough evaluation of the impact of the stratosphere on surface sites. However we have found a number of surface sites that clearly show the 1998-1999 ozone anomaly (see Fig. 4). It is important to stress that many surface sites do not show this major ozone anomaly, in particular the many surface sites over the interior western US analyzed by Jaffe and Ray (2007). A list of the particular surface sites analyzed here is given in Table 1 . These sites have diverse geographic locations and are located between sea level and $3580 \mathrm{~m}$. With the exception of the Egbert site over Southeastern Canada, the correlation amongst these surface sites tends to be highly significant and greater than 0.52 (Table S3). We show only one elevated site over Central Europe, the Jungfraujoch; however, the interannual correlation of ozone measured at all the elevated surface sites we examined in Central Europe (Jungfraujoch, Payerne, Rigi and Sonnblick) is highly significant (not shown). The correlation between each of these sites and Mace Head (at sea level) is also highly significant, suggesting a common cause of variance with incoming air over the Atlantic. We discuss the Mace Head site measurements in more detail in Sect. 4.1. 


\subsection{Correlation between the tropospheric and stratospheric ozone records}

There is a striking similarity between the average measured ozone records constructed at $150 \mathrm{hPa}$ (i.e., the regional ozone records averaged over Canada, Central Europe and Northern Europe, Fig. 3b) and the average measured ozone record constructed at $500 \mathrm{hPa}$ (i.e., the regional ozone records averaged over Canada, the Eastern US and Northern Europe). Both records have ozone minima in 1993, 1997 and 2000 and a maximum in 1999. Both show that after 1999 the ozone appears to level off. We note, however, that the measured peaks in 2002 and 2004 in the averaged $150 \mathrm{hPa}$ ozone record are not echoed in the averaged $500 \mathrm{hPa}$ record; the peak during 2003 in the averaged $500 \mathrm{hPa}$ ozone record is evident in the Central European $150 \mathrm{hPa}$ record, but not in the Canadian or Northern European records. The common variability between the stratosphere and troposphere appears to be largely due to the impact of large timescale events: the relatively low ozone concentrations in 1993, the high concentrations in 1998-1999, and the overall increase of ozone until the late 1990s and the relatively flat record thereafter. The average $150 \mathrm{hPa}$ ozone record explains $68 \%$ of the average $500 \mathrm{hPa}$ record. By averaging the $500 \mathrm{hPa}$ ozone signal amongst different stations we increase the common variance and minimize the regional impacts, isolating the longtimescale, large spatial scale processes. When the average $150 \mathrm{hPa}$ record is correlated individually with $500 \mathrm{hPa}$ station records it explains: between 21 and $51 \%$ of the variance over the Canadian stations; between 25 and $58 \%$ of the variance over Northern European stations and between 40 and $54 \%$ of the variance over the Eastern US. Tarasick et al. (2005), Thouret et al. (2006), Ordoñez et al. (2007) and Terao et al. (2008) have previously noted local correlations between stratospheric and tropospheric ozone.

The ozone evolution at the surface sites has many of the characteristics noted previously at 500 and $150 \mathrm{hPa}$ : ozone minima near 1993, an ozone minimum in 1999 and generally elevated ozone levels after 1999. The average $150 \mathrm{hPa}$ ozone record explains $43 \%$ of the variance of the ozone record averaged over the four surface stations examined. When the average $150 \mathrm{hPa}$ signal is correlated with the individual surface records it explains between 26\% (Ryori) and 54\% (Mace Head) of the variance. It is important to emphasize that we have not completed a comprehensive analysis of all surface sites, we have merely selected a few with a common signal.

\section{Simulated interannual ozone variability}

First the simulated ozone variability and trends are evaluated against measurements. We next examine the simulated tropospheric ozone budget from 1990-2008, first examining the global budget (Sect. 4.2.1), then the $30-90^{\circ} \mathrm{N}$ budget (Sect. 4.2.2). This analysis puts the ozone changes at the
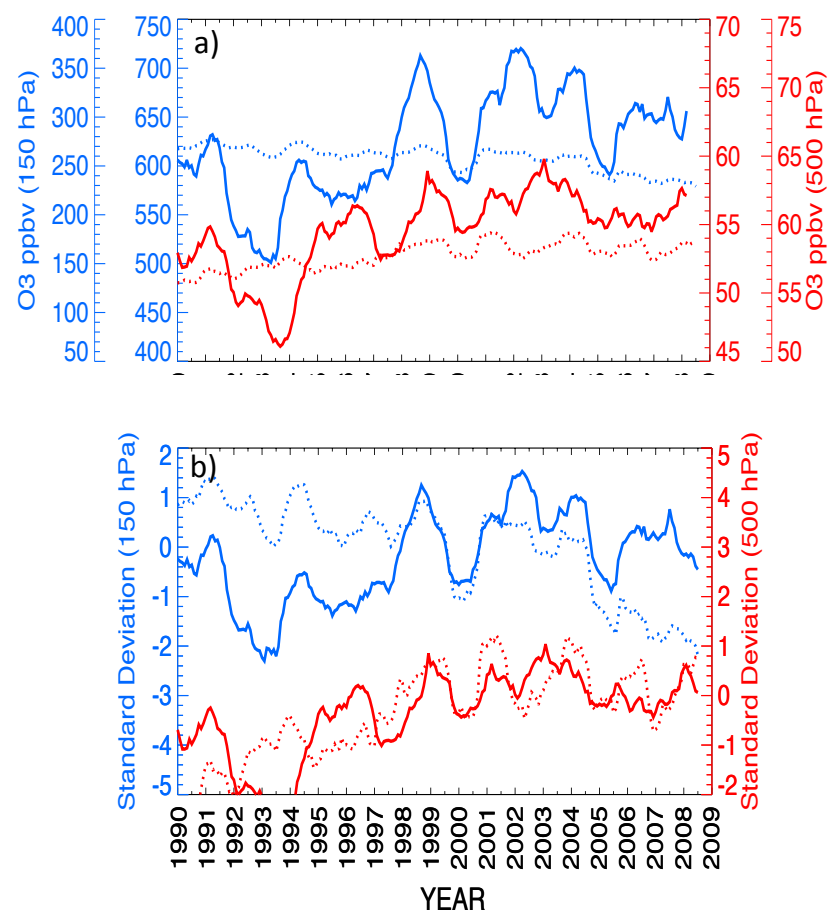

Fig. 5. Simulated (dotted lines) and measured (solid lines) ozone at $150 \mathrm{hPa}$ (blue) and $500 \mathrm{hPa}$ (red). In all cases a 12 month smoothing is used. (a) Ozone (ppbv) at $150 \mathrm{hPa}$ (left scales) and $500 \mathrm{hPa}$ (right scales). Left most and right most scales are for the simulation, innermost scales are for the measurments. (b) Normalized 12-month running mean of regionally averaged simulated and measured ozone measurement anomalies (NS12MD), as analyzed in Fig. 1 at $150 \mathrm{hPa}$ (left scale) and $500 \mathrm{hPa}$ (right scale).

measurement sites into context. Finally, we analyze the vertical ozone correlations in the simulation and in the measurements (in Sect. 4.3). Discussion is given in Sect. 4.4.

\subsection{Model-measurement comparison}

We first construct simulated ozone records by sampling the model at the individual measurement sites. Note that the simulated record at any site is not sampled on the particular days the measurements were made, but instead uses monthly averaged ozone concentrations. Simulated trend calculations use the same monthly sampling at each site as was used to construct the measured trends: months with no valid measurements are also not used in the simulated analysis. Likewise, the average simulated $500 \mathrm{hPa}$ ozone record is constructed using the same stations, regions and monthly sampling as used in the measurements.

We begin this section by illustrating differences between the normalized (NS12MD) and the un-normalized simulated ozone records. As an example of these differences, Fig. 5a gives the un-normalized simulated and measured ozone records averaged over the Canadian stations, Fig. $5 \mathrm{~b}$ gives the normalized records (e.g., the NS12MD). Note that 
Table 2. Measured and simulated ozone at $500 \mathrm{hPa}$ or at the surface for the regions or stations defined in Table 1. Results from measurements are indicated with $\bigcirc$ and from model with $\downarrow$. Numbers in parenthesis give the statistic for the stratospheric portion of simulated ozone $\left(\mathrm{O}_{3 \mathrm{~S}}\right)$ for the mean and standard deviation and the significance of the measurement/model correlation in the last column. Correlations in bold are significant at the $95 \%$ level. Simulated statistics are given in italics. 12-month smoothed ozone deviations are used to compute the table statistics as described in the text. The simulation is sampled at measured sites during those months with more than two independent regional measurements.

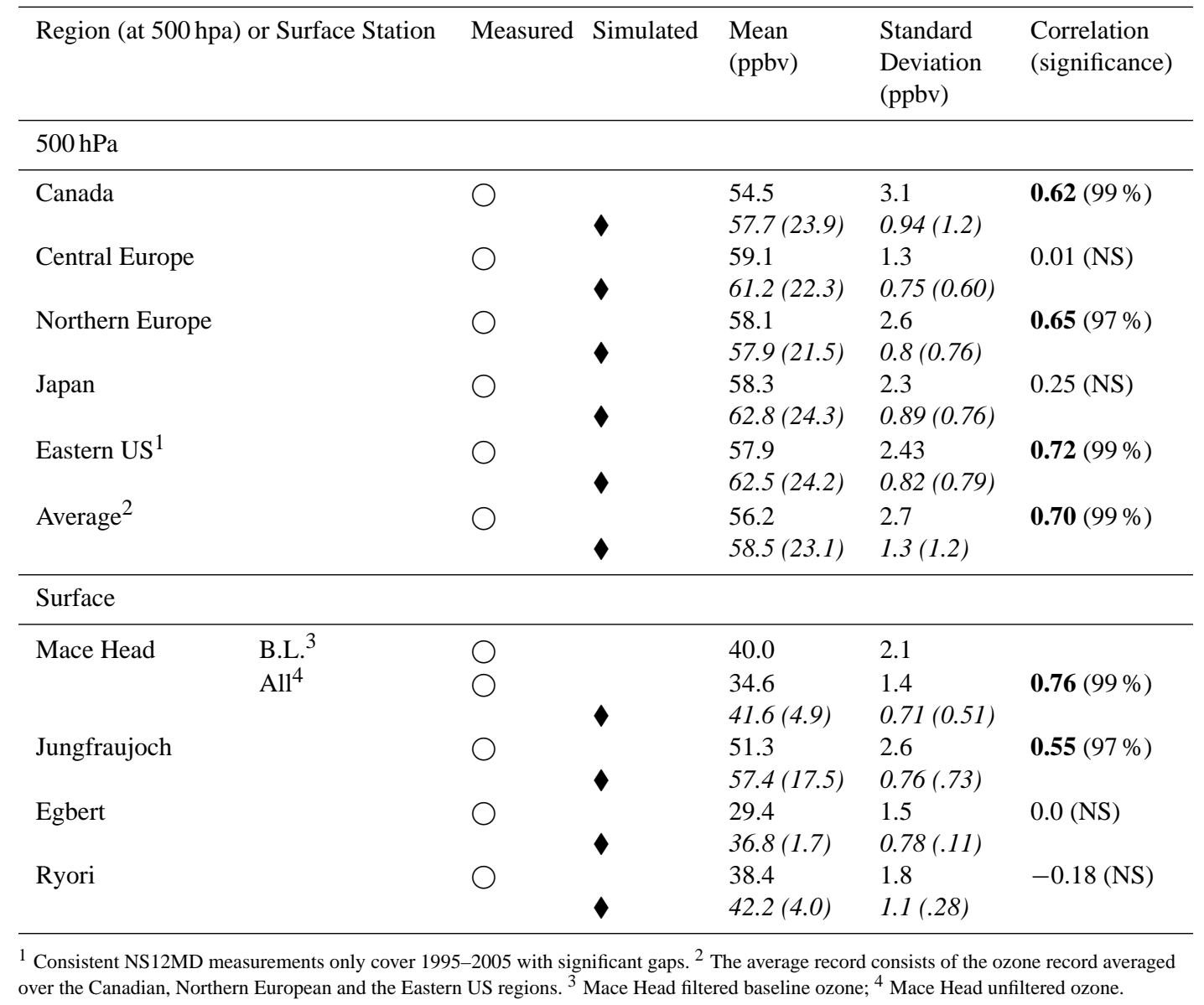

at $150 \mathrm{hPa}$ the simulation dramatically underestimates the measured concentrations: at this height the concentration of simulated ozone is equal to that of synoz*, where synoz* is specified to give the approximately correct ozone STE, but not necessarily the correct ozone concentrations. Nevertheless, as discussed in more detail below the $150 \mathrm{hPa}$ interannual variations in synoz* and measured ozone are clearly related (Sect. 4.3). Simulated ozone has significantly less interannual variability than the measurements at both 150 and $500 \mathrm{hPa}$. In the troposphere the measured interannual variability is three times larger than that simulated (Table 2). Some of this discrepancy could be attributable to the fact that interannual emission variability (except for lightning $\mathrm{NO}_{\mathrm{x}}$ ) is not simulated. However, at the surface, Pozzoli et al. (2011) suggests variability in anthropogenic emissions contributes only $25 \%$ to the overall ozone variability. The use of synoz* could also contribute to the discrepancy between simulated and measured variability as synoz* dramatically underestimates measured ozone at $150 \mathrm{hPa}$ (Fig. 5a).

When we compare simulated and measured NS12MD ozone (Fig. 5b) the agreement between model and measurements improves considerably at both levels. In the remainder of this section we give the model-measurement comparisons in terms of NS12MD. These comparisons better facilitate a visual comparison between simulated and measured variability.

As the model is specifically designed to simulate tropospheric chemistry we focus on the model-measurement comparison at $500 \mathrm{hPa}$ and the surface. The model-measurement comparison at $500 \mathrm{hPa}$ is given in Fig. 6, the surface sites are compared in Fig. 7. Simulated and measured ozone variability and concentrations are given in Table 2 with trends given in Table 3. Additional model evaluation has been discussed above and can be found in the Supplement (Figs. S2S6). Simulated ozone generally overestimates the annually 
Table 3. Measured and simulated annual, winter (DJF) or summer (JJA) ozone trends at $500 \mathrm{hPa}$ or at the surface for the regions or stations defined in Table 1. Results from measurements are indicated with $\bigcirc$ and from model with $\downarrow$. Numbers in italics (last row for each station) give the statistic for the stratospheric portion of simulated ozone $\left(\mathrm{O}_{3 \mathrm{~S}}\right)$. Trend range is given at the $95 \%$ significance level and in bold the trends significantly different from zero at the $95 \%$ confidence level. Trends only computed only for time-periods which have at least 2-measurement stations in each region and for stations with measurements at beginning and end of interval.

\begin{tabular}{|c|c|c|c|c|c|c|c|c|c|}
\hline \multirow{2}{*}{\multicolumn{2}{|c|}{ Region (at $500 \mathrm{hpa}$ ) or Surface Station }} & \multirow[t]{2}{*}{ Measured } & \multirow[t]{2}{*}{ Simulated } & \multicolumn{3}{|c|}{ Trend 1990-2000 (ppbv yr ${ }^{-1}$ ) } & \multicolumn{3}{|c|}{ Trend 2000-2009 (ppbv yr ${ }^{-1}$ ) } \\
\hline & & & & Annual & Winter & Summer & Annual & Winter & Summer \\
\hline \multicolumn{10}{|l|}{$500 \mathrm{hPa}$} \\
\hline \multirow{3}{*}{\multicolumn{2}{|c|}{ Canada }} & $\bigcirc$ & & $0.58 \pm 0.36$ & $0.80 \pm 0.39$ & $0.38 \pm 0.67$ & $-0.05 \pm 0.27$ & $0.21 \pm 0.49$ & $-0.22 \pm 0.83$ \\
\hline & & & $\diamond$ & $0.26 \pm 0.08$ & $0.24 \pm 0.11$ & $0.36 \pm 0.17$ & $0.03 \pm 0.13$ & $-0.15 \pm 0.24$ & $0.19 \pm 0.15$ \\
\hline & & & $\diamond$ & $0.21 \pm 0.07$ & $0.11 \pm 0.16$ & $0.38 \pm 0.12$ & $0.12 \pm 0.13$ & $0.02 \pm 0.17$ & $0.33 \pm 0.18$ \\
\hline \multirow{3}{*}{\multicolumn{2}{|c|}{ Central Europe $^{1}$}} & 0 & & $0.04 \pm 0.56$ & $0.47 \pm 0.60$ & $-0.54 \pm 0.82$ & $0.06 \pm 0.37$ & $0.52 \pm 0.41$ & $-0.25 \pm 0.62$ \\
\hline & & & $\diamond$ & $0.22 \pm 0.09$ & $0.26 \pm 0.15$ & $0.09 \pm 0.28$ & $\mathbf{0 . 1 0} \pm \mathbf{0 . 1 0}$ & $0.06 \pm 0.09$ & $0.14 \pm 0.22$ \\
\hline & & & $\diamond$ & $0.11 \pm 0.05$ & $-0.07 \pm 0.27$ & $0.31 \pm 0.25$ & $0.19 \pm 0.12$ & $0.30 \pm 0.26$ & $-0.01 \pm 0.20$ \\
\hline \multirow{3}{*}{\multicolumn{2}{|c|}{ Northern Europe ${ }^{2}$}} & 0 & & $0.65 \pm 0.45$ & $0.36 \pm 0.69$ & $0.87 \pm 0.89$ & $-0.18 \pm 0.80$ & $0.14 \pm 0.64$ & $-1.21 \pm 0.90$ \\
\hline & & & $\diamond$ & $0.34 \pm 0.15$ & $0.24 \pm 0.18$ & $0.48 \pm 0.28$ & $0.07 \pm 0.26$ & $0.08 \pm 0.43$ & $-0.37 \pm 0.38$ \\
\hline & & & $\diamond$ & $0.24 \pm 0.10$ & $0.14 \pm 0.22$ & $0.41 \pm 0.20$ & $0.26 \pm 0.22$ & $0.17 \pm 0.47$ & $-0.06 \pm 0.32$ \\
\hline \multirow{3}{*}{\multicolumn{2}{|c|}{ Japan $^{3}$}} & $\bigcirc$ & & $0.47 \pm 0.40$ & $0.40 \pm 0.56$ & $1.38 \pm 1.50$ & $0.44 \pm 0.50$ & $0.31 \pm 0.89$ & $1.08 \pm 1.17$ \\
\hline & & & $\diamond$ & $0.17 \pm 0.18$ & $0.21 \pm \mathbf{0 . 1 0}$ & $0.06 \pm 0.59$ & $0.18 \pm 0.19$ & $-0.04 \pm 0.16$ & $0.41 \pm 0.40$ \\
\hline & & & 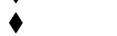 & $0.08 \pm 0.16$ & $0.08 \pm 0.21$ & $0.08 \pm 0.34$ & $0.31 \pm 0.15$ & $0.17 \pm 0.21$ & $0.47 \pm 0.24$ \\
\hline \multirow{3}{*}{\multicolumn{2}{|c|}{ Eastern US ${ }^{4}$}} & $\bigcirc$ & & $1.60 \pm 1.45$ & $2.11 \pm 2.61$ & $-0.17 \pm 5.91$ & $0.39 \pm 0.50$ & $0.11 \pm 1.11$ & $0.52 \pm 1.53$ \\
\hline & & & $\diamond$ & $0.41 \pm 0.56$ & $0.78 \pm 0.66$ & $1.61 \pm 2.15$ & $0.04 \pm 0.36$ & $-0.14 \pm 0.54$ & $0.42 \pm 0.63$ \\
\hline & & & $\boldsymbol{\nabla}$ & $0.27 \pm 0.49$ & $0.24 \pm 0.50$ & $1.02 \pm 1.34$ & $-0.10 \pm 0.58$ & $-0.10 \pm 0.30$ & $0.02 \pm 0.50$ \\
\hline \multicolumn{10}{|l|}{ Surface } \\
\hline \multirow[t]{4}{*}{ Mace Head ${ }^{5}$} & B.L. & $\bigcirc$ & & $0.56 \pm 0.36$ & $0.85 \pm 0.28$ & $0.27 \pm 0.39$ & $0.00 \pm 0.32$ & $-0.03 \pm 0.21$ & $0.01 \pm 0.73$ \\
\hline & All & 0 & & $0.28 \pm 0.33$ & $0.63 \pm 0.71$ & $-0.01 \pm 0.54$ & $0.33 \pm 0.60$ & $0.17 \pm 0.99$ & $0.38 \pm 1.05$ \\
\hline & & & $\diamond$ & $\mathbf{0 . 1 8} \pm \mathbf{0 . 1 3}$ & $0.27 \pm 0.46$ & $-0.11 \pm 0.36$ & $0.02 \pm 0.29$ & $0.13 \pm 0.27$ & $-0.16 \pm 1.05$ \\
\hline & & & $\diamond$ & $0.09 \pm 0.09$ & $0.15 \pm 0.35$ & $0.05 \pm 0.06$ & $-0.02 \pm 0.13$ & $0.04 \pm 0.32$ & $0.00 \pm 0.10$ \\
\hline \multirow{3}{*}{\multicolumn{2}{|c|}{ Jungfraujoch }} & $\bigcirc$ & & $0.76 \pm 0.53$ & $1.13 \pm 0.35$ & $0.71 \pm 0.80$ & $-0.13 \pm 0.35$ & $0.04 \pm 0.29$ & $-0.32 \pm 0.83$ \\
\hline & & & $\diamond$ & $0.16 \pm 0.16$ & $0.21 \pm 0.21$ & $-0.02 \pm 0.44$ & $0.07 \pm 0.17$ & $0.04 \pm 0.12$ & $0.14 \pm 0.35$ \\
\hline & & & $\diamond$ & $0.11 \pm 0.10$ & $-0.07 \pm 0.47$ & $0.29 \pm 0.28$ & $0.09 \pm 0.10$ & $0.27 \pm 0.42$ & $-0.13 \pm 0.27$ \\
\hline \multirow{3}{*}{\multicolumn{2}{|c|}{ Egbert $^{6}$}} & $\bigcirc$ & & $0.36 \pm 0.30$ & $0.05 \pm 0.35$ & $0.47 \pm 0.67$ & NA & NA & NA \\
\hline & & & $\diamond$ & $0.07 \pm 0.19$ & $-0.13 \pm 0.38$ & $0.44 \pm 0.37$ & NA & NA & NA \\
\hline & & & 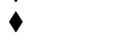 & $0.02 \pm 0.02$ & $-0.02 \pm 0.06$ & $0.04 \pm 0.04$ & NA & NA & NA \\
\hline \multirow[t]{3}{*}{ Ryori $^{7}$} & & $\bigcirc$ & & $0.54 \pm 0.43$ & $0.60 \pm 0.34$ & $0.46 \pm 0.60$ & $0.18 \pm 0.51$ & $0.36 \pm 0.39$ & $0.00 \pm 0.83$ \\
\hline & & & $\diamond$ & $0.13 \pm 0.43$ & $0.26 \pm 0.17$ & $-0.08 \pm 0.60$ & $-0.21 \pm 0.27$ & $-0.06 \pm 0.15$ & $-0.69 \pm 1.04$ \\
\hline & & & $\diamond$ & $0.07 \pm 0.05$ & $0.08 \pm 0.11$ & $0.02 \pm 0.03$ & $0.06 \pm 0.12$ & $0.10 \pm 0.13$ & $0.03 \pm 0.12$ \\
\hline
\end{tabular}

${ }^{1}$ Based only on Hohenpeissenberg and Payerne for 1990-2000 and on Hohenpeissenberg, Debilt and Lindenberg for 2000-2009. ${ }^{2}$ Calculated trends calculated start at 1 January 1991 for the 1990-2000 period; calculated trends end at 1 January 2007 for the 2000-2009 period. Summer and winter trends only calculated through $2006 .{ }^{3}$ Calculated winter trend starts in December 2000 for the 2000-2009 winter period. ${ }^{4}$ Calculated trends start in 1 January 1995 for the 1990-2000 period; calculated trends end in winter 1 January 2006 for the 2000-2009 period. Calculated summer trend begins in 1996 for the 1990-2000 period. ${ }^{5}$ Calculated trend ends in winter 2007 for the $2000-2009$ period because baseline data not available after that date. ${ }^{6}$ No data after 2003. ${ }^{7}$ Calculated summer time trend start in summer of 1991 for the $1990-2000$ period.

averaged measurements slightly at $500 \mathrm{hPa}$ (Table 2), a result of a more substantial overestimate during winter and underestimate during summer (see Supplement). At the surface sites the simulated ozone overestimate is more substantial (Table 2). The simulated stratospheric ozone ranges from over $20 \mathrm{ppbv}$ at $500 \mathrm{hPa}$ to approximately $1-4 \mathrm{ppbv}$ at the lower altitude surface sites, consistent with the results of Fusco and Logan (2003).

The simulated ozone is significantly correlated with the measured ozone record in those regions with a regionally consistent signal at $500 \mathrm{hPa}$, i.e. Canada, the Eastern US and Northern Europe (Table 2 and Fig. 6). Simulated NS12MD ozone tends to be too low near the beginning of the analyzed record in each of these regions. Nevertheless, the simulation clearly captures the sharp increase in ozone between 1995 and 1999, the 1998-1999 ozone maximum, and the flattening of the ozone trend subsequent to 1999 . The sim- ulated ozone maximum in 2001 in the Canadian, the Eastern US, Northern and Central European regions is weakly seen in the Canadian measurements, but not in the other regions (Fig. 6); the measured maximum in 2003 over Northern Europe and Canada is not particularly well captured in the simulation. Over Central Europe and over Japan the simulated and measured ozone are not correlated. As discussed above the Japanese dataset is strongly impacted by the monsoon, likely impacting both the model-measurement correlation as well as the regional trends. Over Central Europe the measured record is not consistent between the different measurement sites. The discrepancy between the simulation and the measurements over Central Europe is particularly poor prior to 1991 . Note, however, that prior to 1991 the analyzed measurement record in Central Europe only consists of two ozonesonde sites and there is a large discrepancy between the ozonesonde measurements and those taken at Jungfraujoch 

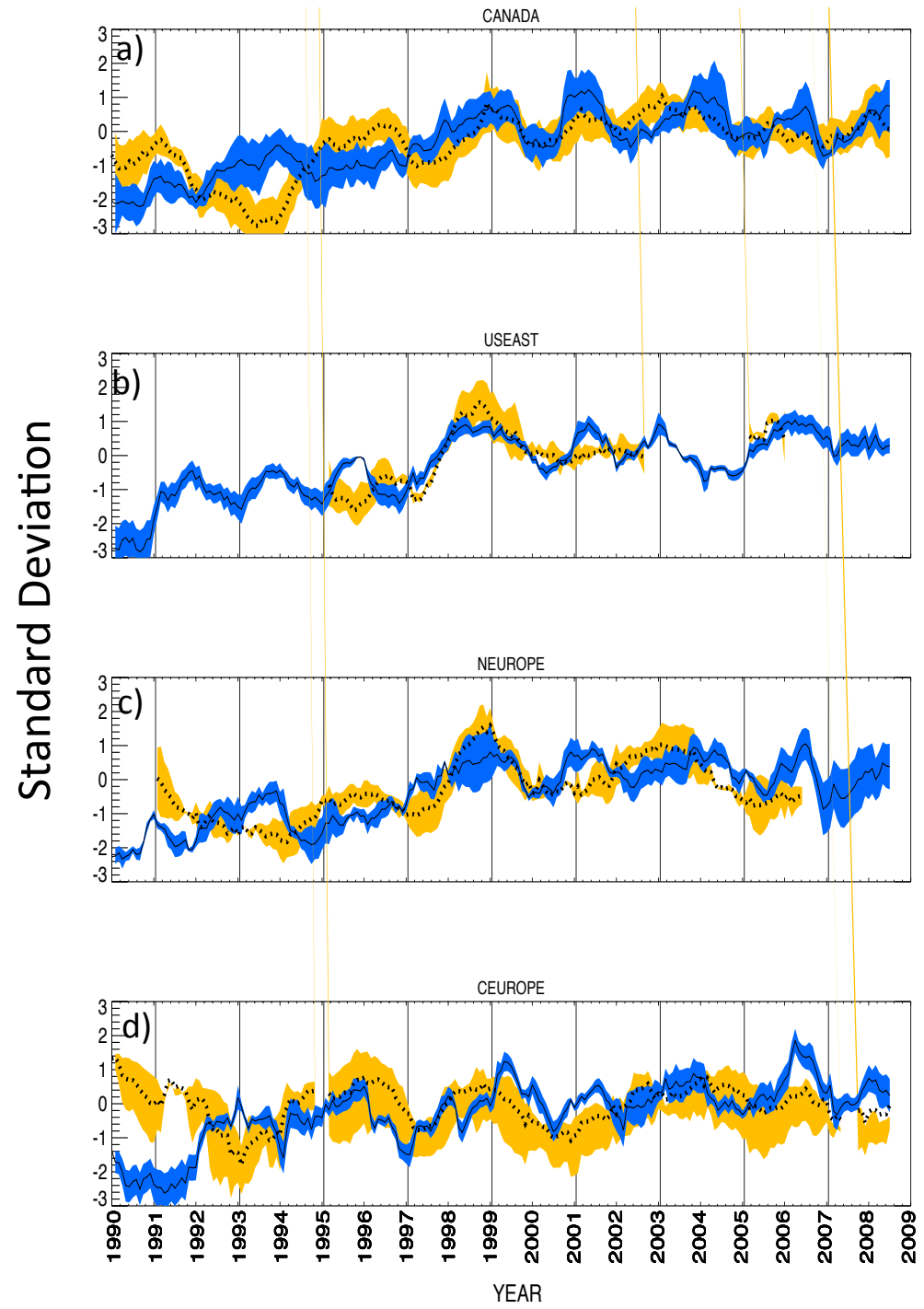

Fig. 6. Simulated and measured ozone record at $500 \mathrm{hPa}$ for various regions: (a) Canada, (b) US East, (c) Northern Europe, (d) Central Europe. Ozone is plotted as the normalized 12-month running mean of the simulated and measured ozone measurement anomalies (NS12MD), as analyzed in Fig. 1. The width of the yellow (blue) shaded region represents two standard deviations of the measured (simulated) ozone over the sites within each region. The dashed (solid) line gives the mean of the measurements (simulation).

(Fig. 2). Jeannet et al. (2007) points out problems with the Payerne data in the early 1990s.

The simulation only captures ozone variability due to meteorological influences and thus will not capture the chemical impacts of the Mt. Pinatubo eruption in the stratosphere (see Fig. 5). The large decrease in the averaged measured ozone at $500 \mathrm{hPa}$ (Figs. 1-3) during the early 1990s is clearly correlated with the decrease in stratospheric ozone ascribed to Pinatubo (Fusco and Logan, 2003; Oltmans et al., 1998). In our analysis this decrease is particularly notable in the Canadian measurements (Figs. 1 and 3). The model-measurement correlation coefficient for the Canadian measurements increases somewhat when the period noticeably impacted by
Mt. Pinatubo (1992-1994) is excluded from the analysis; however, excluding this period has little impact elsewhere.

The simulation suggests that the $500 \mathrm{hPa}$ ozone record sampled over the Canadian, Northern European and or Eastern US measurement sites gives a good representation of the overall $30-90^{\circ} \mathrm{N}$ record. The simulated $500 \mathrm{hPa}$ record averaged over the Canadian, Northern Europe and the Eastern US measurement sites explains, respectively, $87 \%, 84 \%$ and $71 \%$ of the simulated area-averaged $30-90^{\circ} \mathrm{N}$ record. The simulated record averaged over the measurement sites within all three regions explains $91 \%$ of the area-averaged ozone $30-90^{\circ} \mathrm{N}$ record. These results suggest that the measured $500 \mathrm{hPa}$ record averaged over these regions, despite their restricted geographical range and high latitude bias, is 
representative of widespread ozone variations between 30 and $90^{\circ} \mathrm{N}$. However, there is a caveat. At $500 \mathrm{hPa}$ the simulation shows good coherency between the NS12MD records for the Canadian, Eastern US and Northern European regions with inter-regional correlations ranging from approximately 0.8-0.95; however, the respective correlations in the measured data are smaller by approximately one half. This discrepancy could be an artifact of the measurements and/or it may reflect the fact that a substantial portion of regional tropospheric variability is not accounted for in the simulation. The Japanese $500 \mathrm{hPa}$ record explains only $26 \%$ of the areaaveraged $30-90^{\circ} \mathrm{N}$ record. We conclude the variability over Japan is not representative of the large-scale variability, again probably due to the influence of the monsoon.

Model-measurement comparisons at surface sites can be difficult to interpret, as the model does not simulate heterogeneities in local emissions, meteorology and geography. In particular surface sites may be impacted by local emissions, emissions that the simulation does not fully resolve due to its coarse resolution. At the high altitude station of the Jungfraujoch we sample the model at the elevation of the site and not in the simulated surface layer as the model is not able to resolve the actual topography. This type of sampling does not account for the fact that under certain meteorological conditions elevated sites do not measure free-tropospheric air.

At the surface the simulated record is significantly correlated with the measured record at Mace Head and at Jungfraujoch (Fig. 7 and Table 2). At Mace Head, located on the west coast of Ireland, the measurements are split into filtered and unfiltered components, where the filtered measurements are those with trajectories from the clean air sector over the Atlantic Basin (Derwent et al., 2007) (Table 2). The filtered record is designed to represent the baseline conditions at Mace Head (Derwent et al., 2007). The monthly averaged model output makes it impossible to filter the simulated record for baseline conditions at Mace Head. The model output should be compared to the unfiltered record, although it is noteworthy that the baseline and unfiltered ozone records at Mace Head are highly correlated.

The measured and simulated ozone at Mace Head are compared in more detail in Fig. S7. The simulation captures the 1999, 2004 ozone peaks and the 2001 and 2005 minima at Mace Head, but does not capture a number of the details of the measured record between 1994 and 1997 (Fig. 7). The measured ozone records at other high altitude measurement sites over Europe are similar to those at the Jungfraujoch (Ordoñez et al., 2007) and are not further analyzed here. The simulated surface ozone record averaged over the four surface stations examined (Table 1) explains $58 \%$ of the simulated area-averaged $30-90^{\circ} \mathrm{N}$ surface ozone record.

Table 3 gives the annual and seasonal ozone trends for the analyzed $500 \mathrm{hPa}$ regions and the selected surface stations for the two periods: 1990-2000 and 2000-2009. For a number of locations we were not able to make a trend estimate over the entire 10 -yr period due to lack of data so that the trend is only given over a partial interval (see Table 3). Due primarily to missing data at the beginning or end of the period at individual measurement sites, the Central European 1990-2000 trend is only computed with the Payerne and Hohenpeissenberg ozonesonde data. Over the Eastern US the trend analysis is hampered by data availability, as two independent ozone measurements were only available between approximately 1995 and mid-2002, and during much of 2005 (see Fig. 1).

The annually measured 1990-2000 trends at both $500 \mathrm{hPa}$ and the surface are all positive, and are significant except for Central Europe at $500 \mathrm{hPa}$ and for the unfiltered surface data at Mace Head. The measured wintertime trends are all positive and significant at 3 out of the 4 surface stations examined, but only for 1 out of the 5 analyzed $500 \mathrm{hPa}$ regions. None of the measured summertime trends are significant. Again note the substantial inconsistencies in the ozonesonde data over Europe, particularly prior to 1998 (Logan et al., 2012). In general, the simulated trends are generally less than those measured. The simulated 1990-2000 annual trend is positive for all $500 \mathrm{hPa}$ regions and at the surface. Over Canada, Central and Northern Europe the simulated $500 \mathrm{hPa}$ annual trend and wintertime trend are both significant, in the remaining two regions (Japan and the Eastern US) the simulated wintertime trend is significant, but not the annual trend. A detailed analysis of the European alpine and aircraft data (Logan et al., 2012) supports an increase in ozone over Central Europe during the 1990s above the boundary layer, consistent with the model simulation and our analysis of the measurements at Jungfraujoch (Table 3). The simulation shows significant summertime increases at $500 \mathrm{hPa}$ over Canada and Northern Europe and at the surface for Egbert. The measured summertime trends over these regions are positive, but not significant. For the second period examined, 2000-2009, no significant ozone trends are measured either annually or seasonally. The simulation is generally consistent with this. The only significant simulated trends are the annual trend over Central Europe (which is marginally significant) and the summertime trend over Japan.

The simulated trends and variability in the tropospheric ozone are mostly explained by the trend and variability in the stratospheric portion of the ozone. The variability in $\mathrm{O}_{3 \mathrm{~S}}$ accounts for well over $50 \%$ of the total variability for each of the $500 \mathrm{hPa}$ regions (Table 2), as well as at Jungfraujoch and at Mace Head. The average $500 \mathrm{hPa}$ simulated $\mathrm{O}_{3 \mathrm{~S}}$ record (i.e., the $\mathrm{O}_{3 \mathrm{~S}}$ record averaged over the Canadian, Eastern US and Northern European regions) explains $79 \%$ of the average measured $500 \mathrm{hPa}$ variability. The simulated annual trends in stratospheric ozone at the surface also explain $50 \%$ or more of the annual simulated ozone increases (except at Egbert). Seasonal stratospheric trends are significant in summer in a number of regions and significant in winter for the 2000 2009 Central European measurements (Table 3)

The ozone record at Mace Head has been discussed in detail in the literature and is often cited as evidence that 
"background" ozone trends are increasing (Parrish et al., 2009). The increasing surface ozone trends at Mace Head Ireland (Simmonds et al., 2004; Carslaw, 2005; Derwent et al., 2007) have been difficult to explain as this site is far removed from Asia, with its large increases in emissions. Calculations and simulations (Lamarque et al., 2010; Fiore et al., 2009) suggest global emission changes are not sufficient to explain the measured trends at Mace Head. The fact that ozone at Mace Head has leveled off in recent years (Derwent et al., 2007; Simmonds et al., 2004; Carslaw, 2005; Table 3) is also not consistent with the continued increasing trend in Asian emissions after 2000. In a complementary simulation (see Brownsteiner and Hess, 2011) $6 \mathrm{Tg} \mathrm{N}$ of $\mathrm{NO}_{\mathrm{x}}$ emitted from East Asia contributes to $1.3 \mathrm{ppbv}$ ozone at Mace Head. If Chinese emissions of $\mathrm{NO}_{\mathrm{x}}$ increased by $50 \%$ between 1990 and 2000 with emissions in 1990 of $7.0 \mathrm{Tg} \mathrm{N} \mathrm{yr}^{-1}$ (Klimont et al., 2009), the resulting linear sensitivity gives a resulting ozone increase of approximately $0.075 \mathrm{ppbv} \mathrm{yr}^{-1}$ at Mace Head. This is much less than the actual increase (Table 3). Consistent with the analysis of Fiore et al. (2009) our calculations suggest emission changes alone cannot explain the measured ozone increase at Mace Head.

The measured Mace Head ozone record is also highly correlated with ozone measured at the Jungfraujoch (correlation of 0.83, see Supplement Table S3). Ordoñez et al. (2007) shows large and positive correlations between ozone anomalies at the elevated surface sites of Jungfraujoch and Zugspitze and stratospheric ozone anomalies during winter and spring, suggesting that stratospheric ozone variations are responsible for the observed positive winter-spring ozone trends. The measurement analysis and model simulation presented here strongly suggests that the stratosphere is also a strong source of variability at Mace Head. The correlation between the average measured $150 \mathrm{hPa}$ ozone record (Fig. 3b) and the measured baseline ozone, measured unfiltered ozone and simulated surface ozone at Mace Head are $0.73,0.63$ and 0.52 , respectively. The simulated correlation between $\mathrm{O}_{3}$ and $\mathrm{O}_{3}$ at Mace Head is 0.58. Each of these correlations is significant at greater than $98 \%$, using a 2-sided Student's t-test. The ozone change at Mace Head can be equally well fit by assuming a linear trend over the entire period 1990-2009 or by assuming an ozone jump between 1997 and 1999, with low ozone values prior to this time and higher values subsequently. Ozone concentrations in the baseline measurement record, the unfiltered measurement record and model simulation are on average 4.1, 1.9 and $1.0 \mathrm{ppbv}$ higher respectively subsequent to 1999 than prior to 1997 (see Fig. S7). Eighty percent of the simulated jump in ozone between the period prior to 1997 and subsequent to 1999 is due to increases in the stratospheric component of ozone. The simulated ozone trend at Mace Head between 1990 and 2000 is $0.18 \mathrm{ppbv} \mathrm{yr}^{-1}$ (Table 2), with $50 \%$ of the trend due to increases in the stratospheric component of ozone. Both the trend in $\mathrm{O}_{3}$ and $\mathrm{O}_{3}$ S are significant.

\subsection{Tropospheric ozone budget}

\subsubsection{Global ozone budget}

Here we analyze the changes in the global tropospheric burden of ozone, its component produced through $\mathrm{NO}_{\mathrm{x}}$ catalyzed tropospheric chemistry $\left(\mathrm{O}_{3 \mathrm{NO}_{\mathrm{x}}}\right)$, its stratospheric component $\left(\mathrm{O}_{3 \mathrm{~S}}\right)$ and synoz* using monthly averaged model output fields from 1990-2009. Synoz* is representative of stratospheric ozone transported into the troposphere without chemical change, although it is rapidly destroyed in the boundary layer. We define the monthly tropopause height as the first level (from the model top) where the difference between the monthly averaged concentrations of ozone and synoz* is greater than 2 ppbv. We find that a difference of 2 ppbv results in a well-defined and reasonable tropopause height in almost all locations, except near the South Pole where a tighter criterion is occasionally necessary. Above the defined tropopause height ozone and synoz* are always equal and there is little tropospheric influence.

Variations in tropopause height (area averaged), tropospheric water vapor and lightning NO emissions clearly impact tropospheric ozone. Pronounced interannual changes from 1990 through 2008 are simulated in all these quantities (Fig. 8). The simulated global area-weighted tropopause pressure generally decreases, with more pronounced decreases beginning in approximately 1997 and 2005. Measurements of the tropopause pressure suggest a long-term decrease of approximately $-1.7 \pm 0.6 \mathrm{hPa} /$ decade (Seidel and Randel, 2006). Randel et al. (2000) shows that the NCEP reanalysis data captures the interannual variability of tropopause height reasonably well from 1979-1997. Simulated lightning NO emissions increase from 1990-2008. Interestingly, the emissions increase abruptly following the pronounced decreases in tropopause pressure (1996-1997 and 2004-2005). Pozzoli et al. (2011) also finds large interannual variability and trends in lightning $\mathrm{NO}$ emissions, although in contrast to our simulation they find lightning NO emissions decrease between 1990 and 2005. El Niño Southern Oscillation (ENSO) is an important determinate of the tropospheric water vapor column with a particularly pronounced impact during the 1997-1998 El Niño (Trenberth et al., 2005). An associated water vapor peak is clearly visible in Fig. 8. The 1991 water vapor peak might be associated with the 1991-1992 El Niño.

Differences in the tropospheric burden of $\mathrm{O}_{3}$ (solid black), $\mathrm{O}_{3 \mathrm{~S}}$ (dotted black), $\mathrm{O}_{3 \mathrm{NO}_{\mathrm{x}}}$ (blue) and synoz* (green) from their 1990 annually averaged burden $(354 \mathrm{Tg}, 190 \mathrm{Tg}, 164 \mathrm{Tg}$ and $253 \mathrm{Tg}$, respectively) are given in Fig. 9a. In 1999 the global burdens of $\mathrm{O}_{3}$ and $\mathrm{O}_{3}$ s are approximately 7 and $13 \%$ higher than they were in 1990 . The burden of $\mathrm{O}_{3 \mathrm{NO}_{\mathrm{x}}}$ decreases starting in 2000 resulting in a net decrease over the course of the simulation. The timeseries of $\mathrm{O}_{3}, \mathrm{O}_{3} \mathrm{~S}$ and synoz* are highly correlated. All three tracers clearly show the 1998-1999 ozone anomaly, which this simulation 

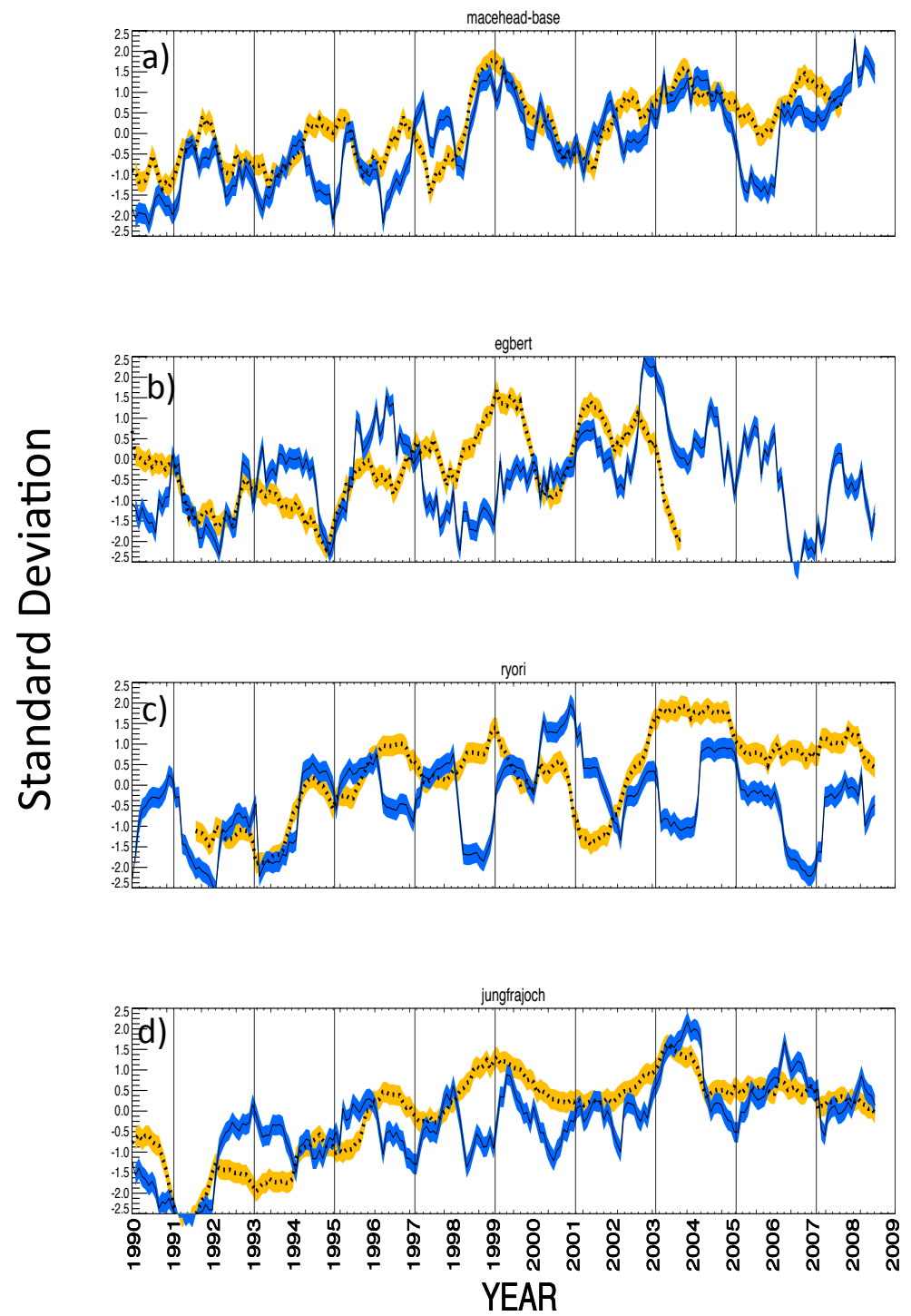

Fig. 7. As in Fig. 6 but for ozone at various surface sites: (a) Mace Head measurements (unfiltered), (b) Egbert, (c) Ryori, (d) Jungfraujoch.

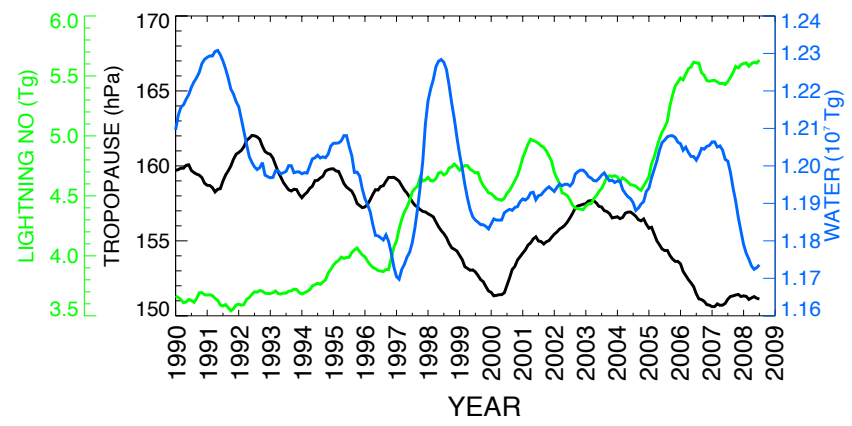

Fig. 8. Simulated 12-month running mean of global lightning NO emissions ( $\mathrm{Tg} \mathrm{Nyr}^{-1}$; Green); area weighted tropopause height (hPa; Black) and tropospheric water vapor burden $\left(\mathrm{Tg} \mathrm{H}_{2} \mathrm{O}\right.$; Blue). suggests, is global in nature. The tropospheric burden of $\mathrm{O}_{3}$, $\mathrm{O}_{3 \mathrm{~S}}$ and synoz* are larger after 1998 than before 1998, although synoz* returns to near its 1990 value at the end of the simulation. However, whereas synoz* shows little overall trend after 2004, $\mathrm{O}_{3}$ and $\mathrm{O}_{3 \mathrm{~S}}$ increase. Differences in the variability and burden of synoz* and $\mathrm{O}_{3 \mathrm{~S}}$ are due to differences in their transport and loss: whereas the flux of $\mathrm{O}_{3 \mathrm{~S}}$ and synoz* from the stratosphere to the troposphere will be the same, the flux from the troposphere to the stratosphere is likely to differ between these species; in addition, whereas $\mathrm{O}_{3 \mathrm{~S}}$ is subject to a spatially and temporally varying chemical sink, synoz* is rapidly destroyed in the lowermost troposphere with a fixed timescale.

The change in the tropospheric ozone burden is equal to the sum of the changes due to tropospheric chemistry, surface deposition and STE. We compute the STE indirectly from the 

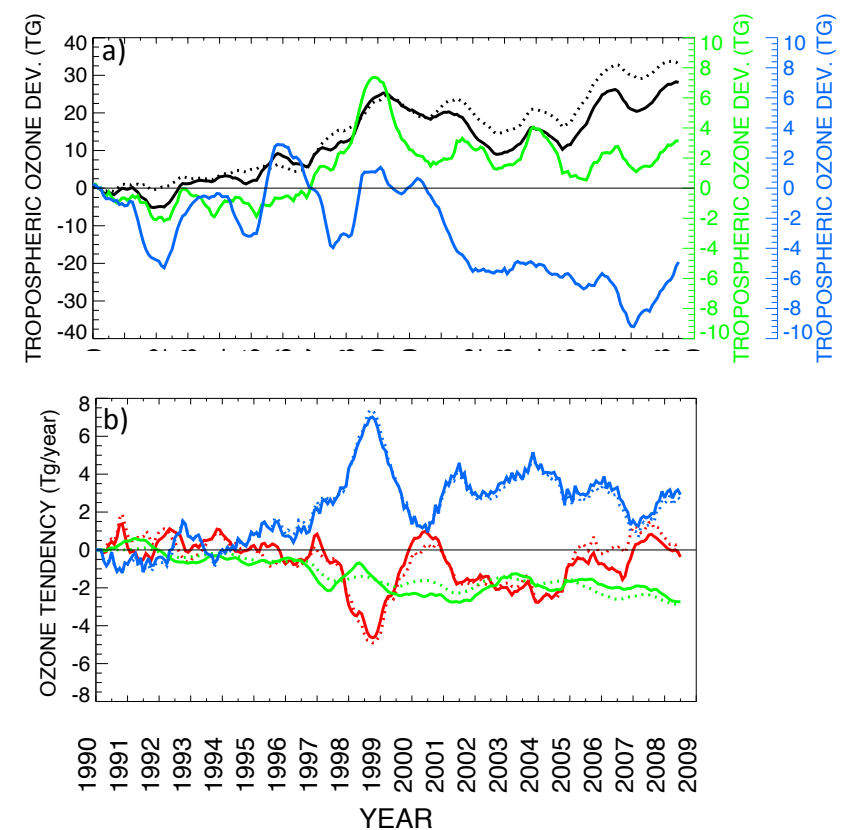

Fig. 9. (a) 12-month smoothed change ( $\mathrm{Tg}$ ) in the global tropospheric the burden of $\mathrm{O}_{3}$ (black, left scale), $\mathrm{O}_{3 \mathrm{~S}}$ (black dotted, right scale), $\mathrm{O}_{3 \mathrm{NO}_{\mathrm{x}}}$ (blue, right scale) and synoz* (green, left scale on right-hand side) from 1990-2008. The change is plotted with respect to the 1990 annual mean burden. (b) 12-month smoothed change $\left(\mathrm{Tg} \mathrm{yr}^{-1}\right)$ for tropospheric $\mathrm{O}_{3}$ (solid lines) and $\mathrm{O}_{3 \mathrm{~S}}$ (dotted lines) burdens due to STE (blue), net chemistry (red) and surface deposition (green). The change is plotted with respect to the 1990 annual mean tendency.

sum of the other budget terms. The use of monthly averaged fields does induce some error in this calculation, however. In particular, we do not explicitly calculate the impact of setting $\mathrm{O}_{3}$ to synoz* and the impact of relaxing $\mathrm{O}_{3 \mathrm{NO}_{\mathrm{x}}}$ to zero. These terms are only non-zero above the instantaneous tropopause; however, they impact the monthly average budget calculation when the instantaneous tropopause dips below the monthly average tropopause. Since they are not explicitly calculated the effect of these terms will be lumped into the calculated STE, which is calculated as a residual. Our analysis suggests these terms are small.

For the year centered about 31 January 1990 the net tropospheric chemical production of ozone is $386.2 \mathrm{Tg} \mathrm{yr}^{-1}$ and the surface deposition is $826.5 \mathrm{Tg} \mathrm{yr}^{-1}$. The estimated gross ozone production and loss are 4630 and $3959 \mathrm{Tg} \mathrm{yr}^{-1}$, respectively. The simulated STE assuming steady-state conditions is $440.4 \mathrm{Tg} \mathrm{yr}^{-1}$, about $10 \%$ of the gross chemical production. The ozone budget is generally consistent with Stevenson et al. (2006). Using a similar calculation for $\mathrm{O}_{3 \mathrm{~S}}$, the surface deposition of $\mathrm{O}_{3 \mathrm{~S}}$ is $112.5 \mathrm{Tg} \mathrm{yr}^{-1}$, its net chemical loss is $369.7 \mathrm{Tg} \mathrm{yr}^{-1}$ and the stratospheric input is $482.2 \mathrm{Tg} \mathrm{yr}^{-1}$. The net STE of $\mathrm{O}_{3}$ and $\mathrm{O}_{3 \mathrm{~S}}$ are within $10 \%$, although the net flux of $\mathrm{O}_{3}$ is somewhat larger. This is as expected: the stratosphere to troposphere flux of $\mathrm{O}_{3}$ and $\mathrm{O}_{3} \mathrm{~S}$ should be approximately the same, while the troposphere to stratosphere flux of $\mathrm{O}_{3}$ should be greater than that of $\mathrm{O}_{3} \mathrm{~S}$ (ozone is greater than $\mathrm{O}_{3 \mathrm{~S}}$ in the troposphere). Note that while the net STE of $\mathrm{O}_{3}$ and $\mathrm{O}_{3}$ S are remarkably similar the budgets of the two are quite different. Net chemistry acts to increase tropospheric $\mathrm{O}_{3}$ while it decreases $\mathrm{O}_{3}$ s and the surface deposition of $\mathrm{O}_{3}$ is much large than that of $\mathrm{O}_{3} \mathrm{~S}$ (its surface concentration is much larger). In 1990 the annual net chemical production of $\mathrm{O}_{3 \mathrm{NO}_{\mathrm{x}}}$ is $756 \mathrm{Tg} \mathrm{yr}^{-1}, 714 \mathrm{Tg} \mathrm{yr}^{-1}$ is lost by surface deposition and the remainder $\left(42 \mathrm{Tg} \mathrm{yr}^{-1}\right)$ is lost through transport to the stratosphere. The net chemical production of $\mathrm{O}_{3 \mathrm{NO}_{\mathrm{x}}}$ is larger than for $\mathrm{O}_{3}$ as it does not include the chemical loss of the stratospheric component of $\mathrm{O}_{3}$. Changes in the $\mathrm{O}_{3 \mathrm{NO}_{\mathrm{x}}}$ burden are primarily determined by changes in its chemistry and surface deposition with neither term clearly dominant (not shown). There is also no simple relationship between changes in lightning $\mathrm{NO}$ emissions and global $\mathrm{O}_{3 \mathrm{NO}_{\mathrm{x}}}$ changes.

The change in net STE (blue lines), net chemistry (red) and surface deposition (green) compared to 1990 is given in Fig. 9b for both $\mathrm{O}_{3}$ (solid lines) and $\mathrm{O}_{3 \mathrm{~S}}$ (dotted lines). In any particular year the changes in these terms are small compared to their overall magnitude. The STE increases in 1997 and remains elevated thereafter compared to pre-1997 levels. The change in the STE of $\mathrm{O}_{3}$ and $\mathrm{O}_{3}$ S are almost indistinguishable from 1990-2008. Changes in the burden of $\mathrm{O}_{3}, \mathrm{O}_{3 \mathrm{~S}}$ and synoz* generally correlate with the changes in STE. In particular the global 1998-1999 ozone anomaly can be ascribed to changes in STE. Voulgarakis et al. (2011) also ascribes the 1998-1999 ozone anomaly to changes in stratospheric ozone flux while Koumoutsaris et al. (2008) traces the more regional ozone anomaly over Europe to both anthropogenic and stratospheric ozone perturbations. It is important to note that changes in STE do not explain the increase in $\mathrm{O}_{3}$ and $\mathrm{O}_{3 \mathrm{~S}}$ after 2004. The STE decreases somewhat after 2004 while the concentrations of $\mathrm{O}_{3}$ and $\mathrm{O}_{3}$ S increase (Fig. 9). The simulated burden of synoz* reflects the variability in the STE. Beginning in 2004 changes in the overall tropospheric chemistry of ozone and $\mathrm{O}_{3}$ S result in an increase in their burden not reflected in the burden of synoz*. The annual averaged lifetime of ozone increases from 27 days at the end of 2004 to 27.7 days in the middle of 2008 , the corresponding lifetime of $\mathrm{O}_{3 \mathrm{NO}_{\mathrm{x}}}$ changes from 19.1 to 19.5 days

Changes in net tropospheric chemistry are anti-correlated with changes in STE on an annual basis and largely compensate for it. Changes in surface deposition also oppose the changes in the STE of $\mathrm{O}_{3}$ and $\mathrm{O}_{3 \mathrm{~S}}$, although there is no clear anticorrelattion on an annual basis between the two terms. The interannual changes in tropospheric chemistry also impact $\mathrm{O}_{3 \mathrm{NO}_{\mathrm{x}}}$ so it might also be expected that $\mathrm{O}_{3 \mathrm{NO}_{\mathrm{x}}}$ would be anticorrelated with $\mathrm{O}_{3 \mathrm{~S}}$. This is not the case on annual timescales, although on long timescales $\mathrm{O}_{3 \mathrm{NO}_{\mathrm{x}}}$ decreases as $\mathrm{O}_{3}$ and $\mathrm{O}_{3 \mathrm{~S}}$ increase (Fig. 9a). 

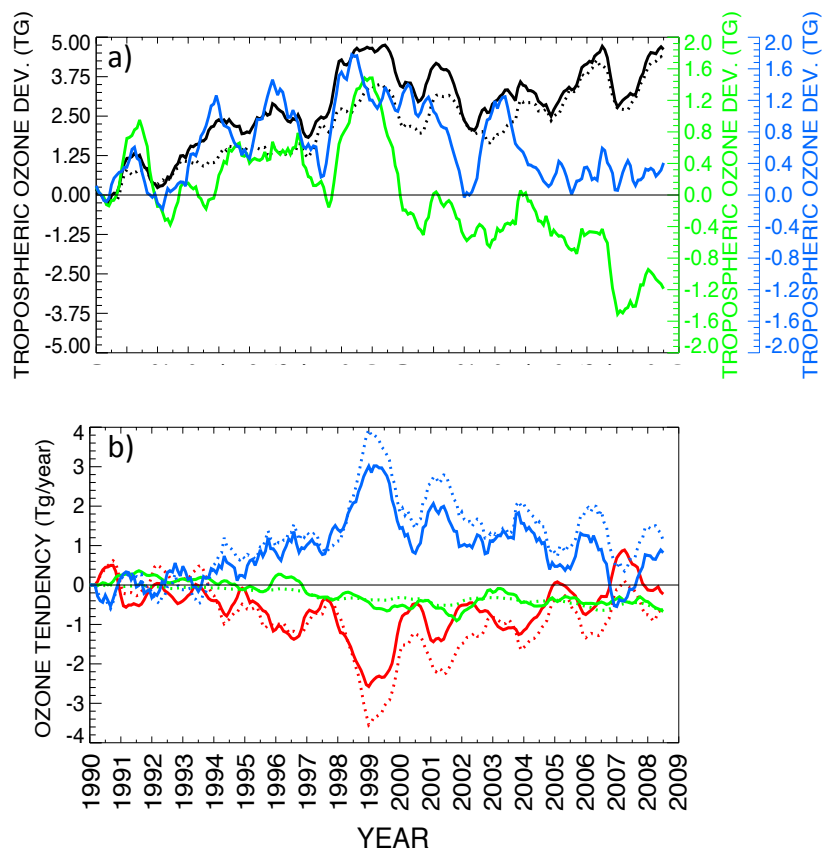

Fig. 10. As in Fig. 9, but for the region from $30-90^{\circ} \mathrm{N}$ with the exception in (b) that the blue line gives total transport into the 30 $90^{\circ} \mathrm{N}$ from the stratosphere and across the $30^{\circ} \mathrm{N}$ lateral boundary.

\subsubsection{Regional ozone budget: $30-90^{\circ} \mathrm{N}$}

We repeat the above analysis for the region from $30-90^{\circ}$. The changes in water vapor, lightning NO and tropopause height in this region are generally similar to the global changes: lightning NO increases throughout the period, the tropopause pressure decreases and water vapor peaks during many of the same years as global water vapor. Differences in the 30$90^{\circ} \mathrm{N}$ tropospheric burden of $\mathrm{O}_{3}$ (black), $\mathrm{O}_{3 \mathrm{~S}}$ (dotted black), $\mathrm{O}_{3 \mathrm{NO}_{\mathrm{x}}}$ (blue) and synoz* (green) from their 1990 annually averaged value $(103,46,57$, and $65 \mathrm{Tg}$, respectively) are given in Fig. 10a. The variability of the $\mathrm{O}_{3}$ and $\mathrm{O}_{3 \mathrm{~S}}$ burdens between $30-90^{\circ} \mathrm{N}$ are generally similar to their globally averaged tropospheric burden with maxima and minima during approximately the same years. As in the global calculation, $\mathrm{O}_{3 \mathrm{~S}}$ and $\mathrm{O}_{3}$ are correlated and are greater after 1998 than prior to that date. The correlation between $\mathrm{O}_{3 S}$ and $\mathrm{O}_{3}$, however, is not as good as in the global calculation. $\mathrm{O}_{3 \mathrm{NO}_{\mathrm{x}}}$ generally increases until 1999 and then decreases; by the end of the period it is not obviously higher than near the beginning. Variations in $\mathrm{O}_{3 \mathrm{NO}_{\mathrm{x}}}$ obviously contribute to some of the $\mathrm{O}_{3}$ variability (e.g., during the years 1993-1994, 19951996 and 2002-2003). While the year-to-year fluctuations in synoz* are correlated with those of $\mathrm{O}_{3} \mathrm{~S}$ and $\mathrm{O}_{3}$, in contrast to those species synoz* decreases after 1999 . At the end of the simulated period synoz* is less than at the beginning.

We calculate changes in the flux of $\mathrm{O}_{3 \mathrm{~S}}$ and $\mathrm{O}_{3}$ into the $30-90^{\circ} \mathrm{N}$ tropospheric column as a residual from their calculated chemical tendency, deposition and ozone burden. How- ever we can no longer ascribe this flux solely to STE; transport across the lateral boundary at $30^{\circ} \mathrm{N}$ is also important. At the beginning of the analyzed time period (1990) the 30$90^{\circ} \mathrm{N}$ chemical production of $\mathrm{O}_{3 \mathrm{NO}_{\mathrm{x}}}$ is $388 \mathrm{Tg} \mathrm{yr}^{-1}$. This is balanced by deposition $275 \mathrm{Tg} \mathrm{yr}^{-1}$ and transport out of the region of $113 \mathrm{Tg} \mathrm{yr}^{-1}$. Transport is much more important than in the global budget. In 1990 the net ozone production is $248 \mathrm{Tg} \mathrm{yr}^{-1}$, the surface deposition is $312 \mathrm{Tg} \mathrm{yr}^{-1}$ and the steady state ozone transported into the $30-90^{\circ} \mathrm{N}$ region is $54 \mathrm{Tg} \mathrm{yr}^{-1}$. The net chemical destruction of $\mathrm{O}_{3 \mathrm{~S}}$ is $140 \mathrm{Tg} \mathrm{yr}^{-1}$, its surface deposition is $27 \mathrm{Tg} \mathrm{yr}^{-1}$ and at steady state its influx into the region is $167 \mathrm{Tg} \mathrm{yr}^{-1}$. As in the global calculation the surface deposition of $\mathrm{O}_{3 \mathrm{~S}}$ is much less than that of ozone and $\mathrm{O}_{3 \mathrm{~S}}$ is chemically destroyed while $\mathrm{O}_{3}$ is chemically produced. However, while the global stratospheric flux of $\mathrm{O}_{3}$ and $\mathrm{O}_{3}$ were within $10 \%$, their net flux into the $30-90^{\circ} \mathrm{N}$ region differ dramatically $\left(167 \mathrm{Tg} \mathrm{yr}^{-1}\right.$ for $\mathrm{O}_{3 \mathrm{~S}}$ versus $54 \mathrm{Tg} \mathrm{yr}^{-1}$ for $\mathrm{O}_{3}$ ). This suggests the lateral export of $\mathrm{O}_{3}$ out of this region is larger than that of $\mathrm{O}_{3} \mathrm{~s}$. This is consistent with strong southward low-level flow out of the $30-90^{\circ} \mathrm{N}$ region (see Bowman and Carrie, 2002) and relatively high concentrations of $\mathrm{O}_{3}$ in the lower troposphere. However, the transport of both species across the lateral $30^{\circ}$ boundary to the region is likely important. The analysis of Tie and Hess (1997) estimate $61 \%$ of the net global stratospheric to tropospheric ozone flux is between $30-90^{\circ} \mathrm{N}$; in our case this result translates into an estimated stratosphere to troposphere flux of $\mathrm{O}_{3 \mathrm{~S}}$ between $30-90^{\circ} \mathrm{N}$ of $294 \mathrm{Tg} \mathrm{yr}^{-1}$. As the inferred influx of $\mathrm{O}_{3 \mathrm{~S}}$ into the region is smaller by about a factor of two $\left(167 \mathrm{Tg} \mathrm{yr}^{-1}\right)$, this implies approximately half the STE of $\mathrm{O}_{3 \mathrm{~S}}$ between $30-90^{\circ} \mathrm{N}$ is exported laterally from the region.

The change in transport (blue), chemistry (red) and surface deposition (green) compared to 1990 for $\mathrm{O}_{3}$ (solid lines) and $\mathrm{O}_{3 \mathrm{~S}}$ (dashed lines) between 30 and $90^{\circ} \mathrm{N}$ is given in Fig. 10b. On the face of it these changes look similar to those in the global budget. Indeed, changes in the transport of $\mathrm{O}_{3}$ and $\mathrm{O}_{3 \mathrm{~S}}$ into the $30-90^{\circ} \mathrm{N}$ region are highly correlated with the global changes. As in the global budget these transport terms determine the overall change in the burden of $\mathrm{O}_{3}$ and $\mathrm{O}_{3 \mathrm{~S}}$. In particular, the prominent 1998-1999 peak is clearly evident in the transport term. The chemistry and transport terms are generally opposed, so that as transport increases ozone the chemical tendency opposes this increase. As in the global budget changes in chemistry are responsible for the slight increase in $\mathrm{O}_{3}$ and $\mathrm{O}_{3 \mathrm{~S}}$ after 2004. However, whereas in the global budget the change in $\mathrm{O}_{3}$ and $\mathrm{O}_{3} \mathrm{~S}$ transport were nearly identical, between $30^{\circ}$ and $90^{\circ} \mathrm{N}$ the change in the transport of $\mathrm{O}_{3 \mathrm{~S}}$ is nearly always greater than that of ozone reflecting the effect of lateral transport. Changes in the 30$90^{\circ} \mathrm{N} \mathrm{O}_{3 \mathrm{NO}_{\mathrm{x}}}$ burden are primarily the result of the interplay between chemistry and transport (the surface deposition is small). Both chemistry and transport contribute to the general increase of $\mathrm{O}_{3 \mathrm{NO}_{\mathrm{x}}}$ through 2000 , while it is the transport that generally contributes to its decrease thereafter. Changes 
in the 1990-2009 burden of synoz* between $30-90^{\circ} \mathrm{N}$ are distinctly different from those of $\mathrm{O}_{3}$ and of $\mathrm{O}_{3 \mathrm{~S}}$ (Fig. 10a). These differences can be attributable to differences in the transport and loss of synoz* in relation to the ozone species. Differences in the budgets of synoz*, $\mathrm{O}_{3}$ and $\mathrm{O}_{3 \mathrm{~S}}$ are discussed in more detail in Sect. 4.4 .

\subsection{Vertical ozone correlations}

Table 4 gives the measured vertical ozone correlation, the simulated vertical ozone correlation and the vertical correlations in synoz* between the 150,300 and $500 \mathrm{hPa}$ levels. It also gives the simulated correlation between ozone and synoz* at each level. We compute the correlations between annually averaged concentrations as well as for two 6-month periods: winter-spring and summer-fall. The 6-month period acts to minimize effect of possible lags between the concentrations on the different levels. We examine the correlations over the Canadian, N. European and Central European regions as these regions include stratospheric and tropospheric measurements. We also compute the correlations when the data is averaged over these three regions and for the simulated area-averaged $30-90^{\circ} \mathrm{N}$ concentrations. Detrended correlations are also given, where we simply correlate deviations from a linear fit through the data. Terao et al. (2008) also examined stratosphere-troposphere correlations in measurements and in a model simulation, but using winds generated from a general circulation model.

Figure 5 gives the $150 \mathrm{hPa}$ simulated and measured ozone record for the Canadian sites. The simulated NS12MD record captures the measured annual ozone minima or maxima during the years 1991, 1994, 1998, 2000, and 2005, although the pronounced measured $150 \mathrm{hPa}$ ozone minimum associated with Pinatubo is not simulated in the current model setup. The simulated normalized $150 \mathrm{hPa}$ ozone anomaly (Fig. $5 \mathrm{~b}$ ) is relatively high compared to that measured from 19901997, but is lower than the measurements after 2006. Consequently, the overall simulated $150 \mathrm{hPa}$ ozone trend (19902009) is negative. In contrast, the measured trend is relatively flat or slightly positive, but with large ozone increases from 1992-1998. The correlation between the detrended and simulated $150 \mathrm{hPa}$ NS12MD ozone timeseries are significant and range from $0.70-0.74$ (not shown) for the three regions (Canada, and Northern and Central Europe); when the timeseries are not detrended the correlation between the measured and simulated ozone at $150 \mathrm{hPa}$ is not significant.

For the Canadian region, the Northern European region and the average of all three regions the $150-300 \mathrm{hPa}$ measured ozone correlation is positive and significant annually, during winter-spring and during summer-fall (Table 4). The simulated $150-300 \mathrm{hPa}$ ozone correlations in the model are positive and generally significant, particularly when measured annually or during the Winter-Spring season. The simulated $150-300 \mathrm{hPa}$ synoz* correlations are all highly significant as is the correlation between ozone and synoz* at
$300 \mathrm{hPa}$ (except in the summer-fall $30-90^{\circ} \mathrm{N}$ average). These results indicate the strong influence of $150 \mathrm{hPa}$ ozone variability on the variability at $300 \mathrm{hPa}$.

The measured $150-500 \mathrm{hPa}$ annual and winter-spring ozone correlations are also positive and significant for the Canadian region, the Northern European region and the average of all three regions; during summer the measured 150$500 \mathrm{hPa}$ correlation is only significant for the Canadian stations and for the average of all three regions. The 150$500 \mathrm{hPa}$ synoz* simulated correlations are significant annually and during winter, suggesting that at these times the stratospheric signal readily propagates downward into the troposphere. During the summer months the simulated 150$500 \mathrm{hPa}$ synoz* correlations are small. The results of Terao et al. (2008) also show the regions with significant vertical stratospheric-tropospheric correlations are much reduced during summer and fall compared to winter and spring. The simulated correlation between 150 and $500 \mathrm{hPa}$ ozone is generally not significant. An inspection of Fig. 5 shows why. Whereas the simulated ozone at $150 \mathrm{hPa}$ is generally decreasing, simulated ozone at $500 \mathrm{hPa}$ is increasing. When the 150 and $500 \mathrm{hPa}$ records are detrended the simulated annual and winter-spring correlations are generally significant and positive, consistent with the measurements.

These results suggests that the simulated annual ozone variability (i.e., the ozone maxima and minima during individual years) propagates downwards on a year-to-year basis from the $150 \mathrm{hPa}$ level to impact the annual and winter-spring $500 \mathrm{hPa}$ record. However, as discussed in the following section an explanation for the different ozone trends between $500 \mathrm{hPa}$ and $150 \mathrm{hPa}$ is somewhat more involved.

\subsection{Discussion}

Globally tropospheric changes in the simulated burdens of $\mathrm{O}_{3}, \mathrm{O}_{3 \mathrm{~S}}$ and synoz* ${ }^{*}$ are generally similar prior to 2004 . After 2004 changes in their tropospheric lifetime cause the $\mathrm{O}_{3}$ and $\mathrm{O}_{3 \mathrm{~S}}$ record to deviate somewhat from that of synoz*. Globally changes in the tropospheric burden of synoz* are highly correlated with STE (Fig. 9). In contrast to the global budget, between 30 and $90^{\circ} \mathrm{N}$ the $\mathrm{O}_{3}, \mathrm{O}_{3 \mathrm{~S}}$ and synoz* records are distinctly different. Between 30 and $90^{\circ} \mathrm{N}$ tropospheric $\mathrm{O}_{3}$ and $\mathrm{O}_{3}$ S increase during the course of the simulation while synoz* decreases. The decrease in synoz* at $500 \mathrm{hPa}$ is clearly related to its decrease at $150 \mathrm{hPa}$ (Table 4 and Fig. 5). These results are consistent the correlations between synoz* and ozone at $500 \mathrm{hPa}$. The annual and winter-spring correlations are generally negative while the detrended correlations are positive on an annual basis and during the winter-spring season (Table 4). As discussed above, the $500 \mathrm{hPa}$ synoz* signal reflects the $150 \mathrm{hPa}$ ozone (synoz*) record.

While year-to-year fluctuations in synoz* and $\mathrm{O}_{3}$ from $30-90^{\circ} \mathrm{N}$ are clearly related through their connection to the stratosphere, another mechanism must be invoked to explain their differing trends. Interannual changes in ozone 
Table 4. Measured and simulated annual, Winter-Spring or Summer-Fall correlations for regions defined in Table 1. Detrended correlations are given in parenthesis. Correlations significant at $95 \%$ shown in bold. Results from measurements are indicated with $\bigcirc$ and from the simulation with $\downarrow$.

\begin{tabular}{|c|c|c|c|c|c|c|c|c|c|c|c|}
\hline \multirow[t]{3}{*}{ Region } & \multirow[t]{3}{*}{ Measured } & \multirow[t]{3}{*}{ Simulated } & \multicolumn{3}{|c|}{$\mathrm{O}_{3}(150 \mathrm{hPa}) / \mathrm{O}_{3}{ }^{1}$} & \multicolumn{3}{|c|}{ Synoz* $(150 \mathrm{hPa}) / \mathrm{Synoz}^{2}$} & \multicolumn{3}{|c|}{ Ozone/Synoz ${ }^{3}$} \\
\hline & & & & Spring & Fall & & Spring & Fall & & Spring & \\
\hline & & & Annual & Winter & Summer & Annual & Winter & Summer & Annual & Winter & Summer \\
\hline \multicolumn{12}{|l|}{$300(\mathrm{hPa})$} \\
\hline \multirow[t]{2}{*}{ Canada } & \multirow[b]{2}{*}{$\bigcirc$} & \multirow[t]{2}{*}{$\diamond$} & $0.87(0.85)$ & $0.93(0.91)$ & $0.44(0.45)$ & \multirow[t]{2}{*}{$0.94(0.88)$} & \multirow[t]{2}{*}{$0.93(0.90)$} & \multirow[t]{2}{*}{$0.92(0.77)$} & \multirow[t]{2}{*}{$0.97(0.97)$} & \multirow[t]{2}{*}{$1.00(1.00)$} & \multirow[t]{2}{*}{$0.68(0.81)$} \\
\hline & & & $0.74(0.62)$ & $0.71(0.63)$ & $\mathbf{0 . 5 4}(0.44)$ & & & & & & \\
\hline Central & \multirow{3}{*}{$\bigcirc$} & $\diamond$ & $0.83(0.84)$ & $0.88(0.87)$ & $0.59(0.68)$ & \multirow[t]{2}{*}{$0.94(0.87)$} & \multirow[t]{2}{*}{$0.93(0.90)$} & \multirow[t]{2}{*}{$0.90(0.75)$} & \multirow[t]{2}{*}{$0.91(0.93)$} & \multirow[t]{2}{*}{$0.95(0.98)$} & \multirow[t]{2}{*}{$0.73(0.77)$} \\
\hline Europe & & & $0.45(\mathbf{0 . 5 9 )}$ & $0.39(\mathbf{0 . 5 0})$ & $0.42(0.49)$ & & & & & & \\
\hline Northern & & $\bullet$ & $0.84(0.85)$ & $0.92(0.90)$ & $0.35(\mathbf{0 . 5 9})$ & \multirow[t]{2}{*}{$0.95(0.88)$} & \multirow[t]{2}{*}{$0.94(0.90)$} & \multirow[t]{2}{*}{$0.94(0.87)$} & \multirow[t]{2}{*}{$0.94(0.97)$} & \multirow[t]{2}{*}{$0.99(0.99)$} & \multirow[t]{2}{*}{$0.57(0.80)$} \\
\hline Europe & \multirow[t]{2}{*}{$\bigcirc$} & & $0.62(0.69)$ & $0.68(0.69)$ & $0.60(0.63)$ & & & & & & \\
\hline \multirow[t]{2}{*}{ Average $^{4}$} & & $\diamond$ & $0.87(0.86)$ & $0.92(0.90)$ & $0.51(0.60)$ & $0.96(0.90)$ & $0.95(0.91)$ & $0.96(0.86)$ & $0.94(0.95)$ & $0.98(0.99)$ & $0.64(0.74)$ \\
\hline & \multirow[t]{2}{*}{$\bigcirc$} & & $0.68(0.70)$ & $0.70(0.76)$ & $0.60(0.63)$ & & & & & & \\
\hline $30-90^{\circ} \mathrm{N}^{5}$ & & $\diamond$ & $0.81(0.66)$ & $0.89(0.76)$ & $0.18(0.44)$ & $0.96(0.83)$ & $0.91(0.76)$ & $0.97(0.89)$ & $0.88(0.85)$ & $0.96(0.96)$ & $0.28(\mathbf{0 . 5 4})$ \\
\hline $500(\mathrm{hPa})$ & & & & & & & & & & & \\
\hline Canada & & $\checkmark$ & $-0.38(\mathbf{0 . 6 4 )}$ & $0.30(\mathbf{0 . 8 1})$ & $-\mathbf{0 . 8 4}(0.01)$ & $0.53(0.73)$ & $0.66(0.67)$ & $0.21(0.46)$ & $0.39(\mathbf{0 . 7 9 )}$ & $0.74(0.89)$ & $0.09(0.32)$ \\
\hline & 0 & & $0.73(0.57)$ & $0.64(0.52)$ & $\mathbf{0 . 6 1}(0.45)$ & & & & & & \\
\hline Central & & 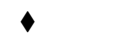 & $-0.49(0.12)$ & $0.08(0.39)$ & $-0.71(-0.26)$ & $0.61(0.53)$ & $\mathbf{0 . 5 8}(0.44)$ & $0.40(0.49)$ & $-0.13(0.24)$ & $0.23(\mathbf{0 . 5 6})$ & $-0.22(0.17)$ \\
\hline Europe & $\bigcirc$ & & $0.46(0.50)$ & $0.45(0.40)$ & $0.33(0.42)$ & & & & & & \\
\hline Northern & & $\diamond$ & $-0.40(\mathbf{0 . 5 3})$ & $0.18(\mathbf{0 . 5 5})$ & $-\mathbf{0 . 7 7}(-0.26)$ & $0.60(0.61)$ & $0.76(0.75)$ & $0.19(0.26)$ & $-0.02(0.36)$ & $0.24(0.38)$ & $0.20(0.42)$ \\
\hline Europe & $\bigcirc$ & & $0.76(0.68)$ & $0.78(0.67)$ & $0.48(0.57)$ & & & & & & \\
\hline Average $^{4}$ & & $\bullet$ & $-0.46(\mathbf{0 . 5 7})$ & $0.11(\mathbf{0 . 6 9 )}$ & $-\mathbf{0 . 7 9}(-0.03)$ & $0.53(0.74)$ & $0.71(0.76)$ & $0.30(\mathbf{0 . 5 6})$ & $0.34(\mathbf{0 . 7 6})$ & $0.49(0.71)$ & $0.18(\mathbf{0 . 5 2})$ \\
\hline & 0 & & $0.85(0.80)$ & $0.82(0.80)$ & $0.74(0.67)$ & & & & & & \\
\hline $30-90^{\circ} \mathrm{N}^{5}$ & & $\diamond$ & $-\mathbf{0 . 5 6}(0.39)$ & $0.02(\mathbf{0 . 6 5})$ & $-\mathbf{0 . 8 5}(-0.17)$ & $0.81(0.73)$ & $0.78(0.57)$ & $0.70(0.72)$ & $-0.20(\mathbf{0 . 6 1})$ & $0.22(0.74)$ & $-0.42(0.04)$ \\
\hline
\end{tabular}

${ }^{1}$ Correlation between ozone at $150 \mathrm{hPa}$ and ozone at either $300 \mathrm{hPa}$ or $500 \mathrm{hPa} .{ }^{2}$ Correlation between synoz* at $150 \mathrm{hPa}$ and synoz* at either $300 \mathrm{hPa}$ or $500 \mathrm{hPa} .{ }^{3}$ Correlation between synoz* and $\mathrm{O}_{3}$ at either $300 \mathrm{hPa}$ or $500 \mathrm{hPa} .{ }^{4}$ Correlation for the average of the Canadian, Northern European and Central European regions. ${ }^{5}$ Area averaged quantity from $30-90^{\circ} \mathrm{N}$.

chemistry do modify the burden of $\mathrm{O}_{3}\left(\mathrm{O}_{3 \mathrm{~S}}\right)$ with respect to synoz; however, it is predominantly transport that controls changes in the burden of $\mathrm{O}_{3}\left(\mathrm{O}_{3 \mathrm{~S}}\right)$ (Fig. 10). Indeed it is transport that drives the overall positive change in $\mathrm{O}_{3}$ $\left(\mathrm{O}_{3 \mathrm{~S}}\right)$ after 1990. However, the high correlation between $\mathrm{O}_{3}$ and synoz* at $300 \mathrm{hPa}$ (Table 4) suggests the transport of $\mathrm{O}_{3}$ $\left(\mathrm{O}_{3 \mathrm{~S}}\right)$ across the tropopause is driving a negative trend in the $\mathrm{O}_{3}\left(\mathrm{O}_{3} \mathrm{~s}\right)$ burden between 30 and $90^{\circ} \mathrm{N}$. We conclude that interannual changes in the lateral transport of $\mathrm{O}_{3}\left(\mathrm{O}_{3 \mathrm{~S}}\right)$ across $30^{\circ} \mathrm{N}$ are acting to increase the $\mathrm{O}_{3}\left(\mathrm{O}_{3} \mathrm{~S}\right)$ burden with respect to 1990 , but have less impact on the burden of synoz*. Unfortunately output statistics for lateral transport were not saved from the model simulation.

Thus ozone trends between 30 and $90^{\circ} \mathrm{N}$ are due to a complex interplay of the trends in $150 \mathrm{hPa}$ ozone, trends in transport across $30^{\circ} \mathrm{N}$ and trends in large-scale chemistry. We find that the stratospheric portion of ozone $\left(\mathrm{O}_{3} \mathrm{~S}\right)$ explains most of the overall changes in ozone. While the simulation does not correctly simulate the overall measured trend in stratospheric ozone over the measurement sites evaluated from $30-90^{\circ} \mathrm{N}$, this does not invalidate the additional mechanisms elucidated above.

\section{Conclusions}

In this paper we analyze both measured and simulated interannual ozone trends and variability from 1990 to 2009 north of $30^{\circ} \mathrm{N}$. Only measurement platforms north of $30^{\circ} \mathrm{N}$ with relatively frequent, consistent and long-term measurements were selected for analysis (Table 1). In addition we required that most of the base period from 1995 through 2005 be regularly sampled at any particular location. We have used observations from ozonesondes, MOZAIC and from selected surface sites to diagnose measured ozone variability at $150 \mathrm{hPa}$ and $500 \mathrm{hPa}$ and the surface. We concentrate our analysis on large spatial-scale and long timescale ozone variability and thus examined the interannual ozone variability for five different regions: Canada, Japan, the Eastern US, and Northern, and Central Europe (see Table 1). We concentrate our analysis on regions with a regionally consistent signal, defined as those regions with at least two independent measurements and a high degree of correlation between the different measurement sites.

Ozone variability is simulated using the CAM-chem model driven by the reanalysis meteorology from the $\mathrm{Na}$ tional Center for Environmental Prediction/National Center for Atmospheric Research (NCEP/NCAR) (Kalnay et al., 1996). Except for lightning $\mathrm{NO}_{\mathrm{x}}$ emissions, there is no interannual emission variability (including biogenic emissions) in these simulations. We estimate the portion of stratospheric ozone transported to the troposphere by tagging tropospheric emissions of $\mathrm{NO}_{\mathrm{x}}$ and calculating the resulting ozone produced, labeled as $\mathrm{O}_{3 \mathrm{NO}_{\mathrm{x}}}$. Stratospheric ozone is diagnosed as the difference between simulated $\mathrm{O}_{3}$ and $\mathrm{O}_{3 \mathrm{NO}_{\mathrm{x}}}$. In the 
stratosphere ozone is parameterized using a modification of the synoz methodology. Simulated ozone is analyzed over the same locations as the measurements. In addition we analyze the global and $30-90^{\circ} \mathrm{N}$ simulated ozone budgets.

The analysis presented here allows us to draw the following conclusions:

1. The simulation in conjunction with the measurements suggests interannual variations in ozone from 19902009 are correlated on hemispheric scales at $500 \mathrm{hPa}$ between 30 and $90^{\circ} \mathrm{N}$. An analysis of $500 \mathrm{hPa}$ ozone measurements over regions where the ozone record is consistent between individual measurement sites (Canada, Northern and the Eastern US) shows the interannual variations in ozone are highly correlated between regions. The simulation suggests that these regions are representative of the large-scale ozone variability between 30 and $90^{\circ} \mathrm{N}$. When the simulation is sampled over these regions the resulting regional ozone records explains between 70 and $90 \%$ of the area-averaged 30$90^{\circ} \mathrm{N} 500 \mathrm{hPa}$ ozone variability; averaging the ozone record over all three regions explains $91 \%$ of the simulated $500 \mathrm{hPa} 30-90^{\circ} \mathrm{N}$ ozone variability.

2. For all regions with a consistent record the $500 \mathrm{hPa}$ measurements show a positive and significant ozone trend from 1990-2000 with no significant trend found between 2000 and 2009. The measured ozone record at $500 \mathrm{hPa}$ is dominated by low ozone concentrations in 1993 and high concentrations in 1998-1999. The low tropospheric concentrations in 1993 appear to be associated with the 1991 Pinatubo eruption as suggested by Oltmans et al. (1998) and Fusco and Logan (2003). The high $500 \mathrm{hPa}$ ozone concentrations in 1998-1999 correspond to an ozone anomaly reported previously in the literature (e.g., Thouret et al., 2006; Zbinden et al., 2006). Our analysis of measurements and the model simulation provide further evidence that this anomaly was very widespread. The $500 \mathrm{hPa}$ measured ozone trend reported here from 1990-2000 is impacted by the low ozone values associated with Pinatubo and the high values in 1998-1999 associated with the ozone anomaly. When the simulation is sampled in the same way we find generally significant and positive trends from 1990-2000 and insignificant trends from 20002009.

3. The high correlation between measured lower stratospheric $(150 \mathrm{hPa})$ and middle tropospheric $(500 \mathrm{hPa})$ ozone suggests stratospheric ozone strongly impacts tropospheric ozone trends and variability. The $150 \mathrm{hPa}$ measured ozone record averaged over regions with a consistent regional signal (Canada, Northern Europe and Central Europe) explains $68 \%$ of the $500 \mathrm{hPa}$ tropospheric ozone record averaged over the tropospheric regions with a consistent regional signal (Canadian,
Northern European and the Eastern US measurement sites). This correlation appears to be at least partially driven by large-scale events including the Mt. Pinatubo eruption and the 1998-1999 ozone anomaly. The simulation shows these sites are representative of $30-90^{\circ} \mathrm{N}$ ozone variability, suggesting the stratospheric signal impacts the troposphere on hemispheric scales.

The simulated trends and variability in $500 \mathrm{hPa} \mathrm{O}_{3}$ between $30-90^{\circ} \mathrm{N}$ are largely explained by the trend and variability in the stratospheric portion $\left(\mathrm{O}_{3 \mathrm{~S}}\right)$ of ozone. Simulated variability is approximately one half to one third of that measured. The $500 \mathrm{hPa}$ simulated $\mathrm{O}_{3 \mathrm{~S}}$ record averaged over the Canadian, Eastern US and Northern European regions explains $79 \%$ of the $500 \mathrm{hPa}$ simulated $\mathrm{O}_{3}$ variability averaged over the same regions. The simulation also shows that at least $50 \%$ of the simulated trends between 1990 and 2000 are due to trends in $\mathrm{O}_{3 \mathrm{~S}}$.

4. Changes in the burden of $\mathrm{O}_{3}$ and $\mathrm{O}_{3 \mathrm{~S}}$ between 30 and $90^{\circ} \mathrm{N}$ reflects a complex interplay of changes in STE, the lateral transport of $\mathrm{O}_{3}$ across $30^{\circ} \mathrm{N}$ and in the chemical loss of ozone. The simulated year-to-year variability of $\mathrm{O}_{3}$ and $\mathrm{O}_{3} \mathrm{~S}$ at $500 \mathrm{hPa}$ reflects the variability at $150 \mathrm{hPa}$. While the simulated year-to-year fluctuations in simulated ozone are consistent with those measured at $150 \mathrm{hPa}$, the overall simulated trend is not. The increasing trend in $\mathrm{O}_{3}$ and $\mathrm{O}_{3}$ S in the $30-90^{\circ} \mathrm{N}$ regions is largely explained by changes in the transport of ozone across $30^{\circ} \mathrm{N}$. In the $30-90^{\circ} \mathrm{N}$ region changes in the tropospheric burden of synoz* and that of $\mathrm{O}_{3 \mathrm{~S}}$ do not always not track each other.

5. In both the simulation and the measurements averaging over large spatial scales increases the interannual correlation between the stratospheric and tropospheric signals. Averaging acts to minimize local sources of variance and isolate common sources of variance due to STE. For example, the measurements averaged over regions with a consistent regional signal at $150 \mathrm{hPa}$ explain $68 \%$ of the variability of the $500 \mathrm{hPa}$ record averaged over regions with a consistent regional signal, but $21-54 \%$ of the $500 \mathrm{hPa}$ record over individual sites. Averaged over the Canadian, US and Northern European regions the simulated stratospheric ozone at $500 \mathrm{hPa}$ explains $79 \%$ of the ozone variability, but when examined over specific regions it explains on average approximately $50 \%$ of the variance at any particular site.

6. While we did not extensively investigate the surface ozone record, both the measurement analysis and model simulation strongly suggests that the stratosphere can exert a strong influence on surface ozone variability and trends. Due to relatively rapid isentropic mixing there can be little doubt that the stratospheric signal detected at $500 \mathrm{hPa}$ also impacts surface sites. Rapid mixing 
along poleward and upward sloping isentropic surfaces (Bowman and Carrie, 2002) connects surface ozone changes with upper and middle tropospheric changes thousands of kilometers to the north. Nevertheless, at the surface local sources of ozone precursor emissions are likely to exert a profound local control on the variability, linking the variability to local-to regional emission sources and local meteorological variability. At the surface locations near sea-level we find between 1 and $5 \mathrm{ppbv}$ of ozone is of stratospheric origin. Thus any stratospheric signal at the surface will likely be difficult to detect at any individual station, but averaging over many stations may isolate the stratospheric signal.

The influence of the stratosphere at the surface appears to be particularly pronounced at the Mace Head measurement site and at the Jungfraujoch site (as shown by Ordoñez et al., 2007), where the correlation between measured and simulated ozone is positive and significant. The variability in $\mathrm{O}_{3 \mathrm{~S}}$ accounts for well over $50 \%$ of the total variability at Jungfraujoch and at Mace Head. The measured baseline ozone record at the Mace Head site is highly correlated with the average stratospheric ozone signal (correlation of 0.73 ) and with the record at the Jungfraujoch site (correlation of 0.83), as well as the ozone record at other high altitude surface ozone sites over Europe (not shown). The simulated correlation between ozone and its stratospheric component $\left(\mathrm{O}_{3 \mathrm{~S}}\right)$ at Mace Head is 0.58 and the stratospheric component of ozone $\left(\mathrm{O}_{3 \mathrm{~S}}\right)$ explains $80 \%$ of the simulated ozone jump at Mace Head between the period prior to 1997 and subsequent to 1999.

7. The interannual global changes in simulated STE, net chemistry and deposition are small compared with the gross ozone production and loss. Nevertheless, their changes increase the troposphere global burden of $\mathrm{O}_{3}$ and $\mathrm{O}_{3 \mathrm{~S}}$ between 1990 and 1999 by approximately $7 \%$ and $13 \%$, respectively. The model simulation suggests that globally STE increased in 1998-1999 in conjunction with a global ozone anomaly. Interannual changes in the simulated global tropospheric ozone burden from 1990-2009 are largely explained by the changes in its stratospheric component. These changes can be largely attributed to changes in STE, but not exclusively. Changes in the tropospheric chemical ozone lifetime are also been important, particularly after 2004 .

In conclusion the model simulations and the measurements are consistent with interannual stratospheric ozone variability on large spatial scales driving tropospheric variability on large scales. This variability extends to the surface. The results are also consistent with non-negligible tropospheric ozone trends, both at the surface and in the free troposphere being driven through variations in stratospheric ozone in the troposphere. However, a number of aspects of the simulation need improvement. While the annual bias in simulated ozone is generally small at $500 \mathrm{hPa}$, the simulation is biased high in winter and low in summer. The interannual variance of simulated ozone is significantly less than observed. However, when the simulated and measured ozone deviations are normalized by their standard deviation the measured and simulated ozone records become comparable. Simulated tropospheric ozone trends are generally less than measured. The year-to-year variability of simulated ozone at $150 \mathrm{hPa}$ shows good correspondence with the measurements but the overall trend is not consistent with those measured. As a consequence the simulated vertical ozone correlations between 150 and $500 \mathrm{hPa}$ are not consistent with those measured. In addition reanalysis winds must be used with caution as they may poorly capture long-term changes in the atmospheric circulation. A better quantification of the tropospheric trends that can be attributed to the stratosphere will require more sophisticated simulations including better representations of stratospheric chemistry and atmospheric circulation.

\section{Supplementary material related to this article is available online at: http://www.atmos-chem-phys.net/13/ 649/2013/acp-13-649-2013-supplement.pdf.}

Acknowledgements. The ozonesonde data was provided from the World Ozone and Ultraviolet Radiation Data Centre (WOUDC) operated by Environment Canada, Toronto, Ontario, Canada under the auspices of the World Meteorological Organization. The data from the surface sites were downloaded from the World Data Centre for Greenhouse Gases, and were contributed by Federal Environment Agency Austria, Swiss Federal Laboratories for Materials Testing and Research, Japan Meteorological Agency, Environment Canada. Authors greatly acknowledge the European Commission and INSU-CNRS for funding as the Airbus support and the following airliners Lufthansa, Air France, Austrian and former Sabena who have been carrying the MOZAIC instrumentation free of charge since 1994. We gratefully acknowledge ETHER (CNES-CNRS/INSU) for hosting the MOZAIC database (http://www.pole-ether.fr). We thank Richard Derwent for help obtaining the data at Mace Head, Ireland. We also wish to thank three anonymous reviewers and Jennifer Logan who greatly improved this work through their constructive comments. This work was supported by the NSF grant AGS-1042787.

Edited by: P. Haynes

\section{References}

Anenberg, S. C., West, J. J., Fiore, A. M., Jaffe, D. A., Prather, M. J., Bergmann, D., Cuvelier, K., Dentener, F. J., Duncan, B. N., and Gauss, M.: Intercontinental impacts of ozone pollution on human mortality, Environ. Sci. Technol., 43, 6482-6487, 2009.

Bell, M. L., McDermott, A., Zeger, S. L., Samet, J. M., and Dominici, F.: Ozone and short-term mortality in 95 US urban communities, 1987-2000, Jama, 292, 2372-2378, 2004. 
Bey, I., Jacob, D. J., Yantosca, R. M., Logan, J. A., Field, B., Fiore, A. M., Li, Q., Liu, H., Mickley, L. J., and Schultz, M.: Global modeling of tropospheric chemistry with assimilated meteorology: Model description and evaluation, J. Geophys. Res., 106, 23073-23096, 2001.

Bowman, K. P. and Carrie, G. D.: The mean-meridional transport circulation of the troposphere in an idealized GCM, J. Atmos. Sci., 59, 1502-1514, 2002.

Brown-Steiner, B. and Hess, P.: Asian influence on surface ozone in the United States: A comparison of chemistry, seasonality, and transport mechanisms, J. Geophys. Res., 116, D17309, doi:10.1029/2011JD015846, 2011.

Butchart, N., Scaife, A. A., Bourqui, M., de Grandpre, J., Hare, S. H. E., Kettleborough, J., Langematz, U., Manzini, E., Sassi, F., and Shibata, K.: Simulations of anthropogenic change in the strength of the Brewer-Dobson circulation, Clim. Dynam., 27, 727-741, 2006.

Carslaw, D. C.: On the changing seasonal cycles and trends of ozone at Mace Head, Ireland, Atmos. Chem. Phys., 5, 34413450, doi:10.5194/acp-5-3441-2005, 2005.

Chameides, W. L., Kasibhatla, P. S., Yienger, J., and Levy, H.: Growth of continental-scale metro-agro-plexes, regional ozone pollution, and world food production, Science, 264, 74-77, doi:10.1126/science.264.5155.74, 1994.

Collins, W. D., Rasch, P. J., Boville, B. A., Hack, J. J., McCaa, J. R., Williamson, D. L., and Briegleb, B. P.: The formulation and atmospheric simulation of the community atmosphere model version 3 (CAM3), J. Climate, 19, 2144-2161, 2006.

Collins, W. J., Derwent, R. G., Garnier, B., Johnson, C. E., Sanderson, M. G., and Stevenson, D. S.: Effect of stratospheretroposphere exchange on the future tropospheric ozone trend, J. Geophys. Res, 108, 8528, doi:10.1029/2002JD002617, 2003.

Cooper, O., Parrish, D., Stohl, A., Trainer, M., Nédélec, P., Thouret, V., Cammas, J., Oltmans, S., Johnson, B., and Tarasick, D.: Increasing springtime ozone mixing ratios in the free troposphere over western north america, Nature, 463, 344-348, doi:10.1038/nature08708, 2010.

Dahlmann, K., Grewe, V., Ponater, M., and Matthes, S.: Quantifying the contributions of individual $\mathrm{NO}_{\mathrm{x}}$ sources to the trend in ozone radiative forcing, Atmos. Environ., 45, 2860-2868, 2011.

De Backer, H., De Muer, D., and De Sadelaer, G.: Comparison of ozone profiles obtained with Brewer-Mast and Z-ECC sensors during simultaneous ascents, J. Geophys. Res., 103, 1964119648, doi:10.1029/98JD01711, 1998.

Derwent, R., Simmonds, P., Manning, A., and Spain, T.: Trends over a 20-year period from 1987 to 2007 in surface ozone at the atmospheric research station, Mace Head, Ireland, Atmos. Environ., 41, 9091-9098, 2007.

Ellingsen, K., Gauss, M., Van Dingenen, R., Dentener, F. J., Emberson, L., Fiore, A. M., Schultz, M. G., Stevenson, D. S., Ashmore, M. R., Atherton, C. S., Bergmann, D. J., Bey, I., Butler, T., Drevet, J., Eskes, H., Hauglustaine, D. A., Isaksen, I. S. A., Horowitz, L. W., Krol, M., Lamarque, J. F., Lawrence, M. G., van Noije, T., Pyle, J., Rast, S., Rodriguez, J., Savage, N., Strahan, S., Sudo, K., Szopa, S., and Wild, O.: Global ozone and air quality: a multi-model assessment of risks to human health and crops, Atmos. Chem. Phys. Discuss., 8, 2163-2223, doi:10.5194/acpd8-2163-2008, 2008.
Emmons, L., Hess, P., Klonecki, A., Tie, X., Horowitz, L., Lamarque, J.-F., Kinnison, D., Brasseur, G., Atlas, E., Browell, E., Cantrell, C., Eisele, F., Mauldin, R. L., Merrill, J., Ridley, B., and Shetter, R.: Budget of tropospheric ozone during TOPSE from two chemical transport models, J. Geophys. Res., 108, 8372, doi:10.1029/2002JD002665, 2003.

Emmons, L. K., Walters, S., Hess, P. G., Lamarque, J.-F., Pfister, G. G., Fillmore, D., Granier, C., Guenther, A., Kinnison, D., Laepple, T., Orlando, J., Tie, X., Tyndall, G., Wiedinmyer, C., Baughcum, S. L., and Kloster, S.: Description and evaluation of the Model for Ozone and Related chemical Tracers, version 4 (MOZART-4), Geosci. Model Dev., 3, 43-67, doi:10.5194/gmd3-43-2010, 2010.

Emmons, L. K., Hess, P. G., Lamarque, J.-F., and Pfister, G. G.: Tagged ozone mechanism for MOZART-4, CAM-chem and other chemical transport models, Geosci. Model Dev., 5, 15311542, doi:10.5194/gmd-5-1531-2012, 2012.

Fiore, A. M., Jacob, D. J., Field, B. D., Streets, D. G., Fernandes, S. D., and Jang, C.: Linking ozone pollution and climate change the case for controlling methane, Geophys. Res. Lett., 29, 1919, doi:10.1029/2002GL015601, 2002.

Fiore, A., Dentener, F., Wild, O., Cuvelier, C., Schultz, M., Hess, P., Textor, C., Schulz, M., Doherty, R., and Horowitz, L.: Longrange transport, tropospheric ozone, pollution, J. Geophys. Res., 114, D04301, doi:10.1029/2008JD010816, 2009.

Forster, P. and Shine, K. P.: Radiative forcing and temperature trends from stratospheric ozone changes, J. Geophys. Res, 102, 10841-10855, doi:10.1029/96JD03510, 1997.

Forster, P., Ramaswamy, V., Artaxo, P., Berntsen, T., Betts, R., Fahey, D. W., Haywood, J., Lean, J., Lowe, D. C., and Myhre, G.: Changes in Atmospheric Constituents and in Radiative Forcing, in: Climate Change 2007: The Physical Science Basis. Contribution of Working Group I to the Fourth Assessment Report of the Intergovernmental Panel on Climate Change, edited by: Solomon, S., Qin, D., Manning, M., Chen, Z., Marquis, M., Averyt, K. B., Tignor, M., and Miller, H. L., Cambridge University Press, Cambridge, United Kingdom and New York, NY, USA, 2007.

Fusco, A. C. and Logan, J. A., Analysis of 1970-1995 trends in tropospheric ozone at Northern Hemisphere midlatitudes with the GEOS-CHEM model, J. Geophys. Res., 108, 4449, doi:10.1029/2002JD002742, 2003.

Grewe, V.: Technical Note: A diagnostic for ozone contributions of various $\mathrm{NO}_{\mathrm{x}}$ emissions in multi-decadal chemistryclimate model simulations, Atmos. Chem. Phys., 4, 729-736, doi:10.5194/acp-4-729-2004, 2004.

Hadjinicolaou, P., Pyle, J. A., Chipperfield, M. P., and Kettleborough, J. A.: Effect of interannual meteorological variability on mid-latitude $\mathrm{O}_{3}$, Geophys. Res. Lett., 24, 2993-2996, doi:10.1029/97GL03055, 1997.

Hegglin, M. I. and Shepherd, T. G.: Large climate-induced changes in ultraviolet index and stratosphere-to-troposphere ozone flux, Nat. Geosci., 2, 687-691, 2009.

Hess, P. G. and Lamarque, J.: Ozone source attribution and its modulation by the arctic oscillation during the spring months, J. Geophys. Res., 112, D11303, doi:10.1029/2006JD007557, 2007.

Hsu, J. and Prather, M. J.: Stratospheric variability and tropospheric ozone, J. Geophys. Res., 114, D06102, doi:10.1029/2008JD010942, 2009. 
Jaffe, D. and Ray, J.: Increase in surface ozone at rural sites in the western US, Atmos. Environ., 41, 5452-5463, 2007.

Jaffe, D., Price, H., Parrish, D., Goldstein, A., and Harris, J.: Increasing background ozone during spring on the west coast of North America, Geophys. Res. Lett, 30, 1613, doi:10.1029/2003GL017024, 2003.

Jeannet, P., Stübi, R., Levrat, G., Viatte, P., and Staehelin, J.: Ozone balloon soundings at Payerne (Switzerland): Reevaluation of the time series 1967-2002 and trend analysis, J. Geophys. Res., 112, D11302, doi:10.1029/2005JD006862, 2007.

Jonson, J. E., Stohl, A., Fiore, A. M., Hess, P., Szopa, S., Wild, O., Zeng, G., Dentener, F. J., Lupu, A., Schultz, M. G., Duncan, B. N., Sudo, K., Wind, P., Schulz, M., Marmer, E., Cuvelier, C., Keating, T., Zuber, A., Valdebenito, A., Dorokhov, V., De Backer, H., Davies, J., Chen, G. H., Johnson, B., Tarasick, D. W., Stübi, R., Newchurch, M. J., von der Gathen, P., Steinbrecht, W., and Claude, H.: A multi-model analysis of vertical ozone profiles, Atmos. Chem. Phys., 10, 5759-5783, doi:10.5194/acp-10-57592010, 2010.

Kalnay, E., Kanamitsu, M., Kistler, R., Collins, W., Deaven, D., Gandin, L., Iredell, M., Saha, S., White, G., Woollen, J., Zhu, Y., Chelliah, M., Ebisuzaki, W., Higgins, W., Janowiak, J., Mo, K. C., Ropelewski, C., Wang, J., Leetmaa, A., Reynolds, R., Jenne, R., and Joseph, D.: The NCEP/NCAR 40-year reanalysis project, B. Am. Meteorol. Soc., 77, 437-471, 1996.

Klimont, Z., Cofala, J., Xing, J., Wei, W., Zhang, C., Wang, S., Kejun, J., Bhandari, P., Mathur, R., and Purohit, P.: Projections of $\mathrm{SO}_{2}, \mathrm{NO}_{\mathrm{x}}$ and carbonaceous aerosols emissions in asia, Tellus B, 61, 602-617, 2009.

Koumoutsaris, S., Bey, I., Generoso, S., and Thouret, V.: Influence of El Niño-Southern oscillation on the interannual variability of tropospheric ozone in the northern midlatitudes, J. Geophys. Res., 113, D19301, doi:10.1029/2007JD009753, 2008.

Lamarque, J.-F., Bond, T. C., Eyring, V., Granier, C., Heil, A., Klimont, Z., Lee, D., Liousse, C., Mieville, A., Owen, B., Schultz, M. G., Shindell, D., Smith, S. J., Stehfest, E., Van Aardenne, J., Cooper, O. R., Kainuma, M., Mahowald, N., McConnell, J. R., Naik, V., Riahi, K., and van Vuuren, D. P.: Historical (1850-2000) gridded anthropogenic and biomass burning emissions of reactive gases and aerosols: methodology and application, Atmos. Chem. Phys., 10, 7017-7039, doi:10.5194/acp10-7017-2010, 2010.

Lamarque, J.-F., Emmons, L. K., Hess, P. G., Kinnison, D. E., Tilmes, S., Vitt, F., Heald, C. L., Holland, E. A., Lauritzen, P. H., Neu, J., Orlando, J. J., Rasch, P. J., and Tyndall, G. K.: CAM-chem: description and evaluation of interactive atmospheric chemistry in the Community Earth System Model, Geosci. Model Dev., 5, 369-411, doi:10.5194/gmd-5-369-2012, 2012.

Lelieveld, J. and Dentener, F.: What controls tropospheric ozone?, J. Geophys. Res., 105, 3531-3551, 2000.

Lelieveld, J., Van Aardenne, J., Fischer, H., De Reus, M., Williams, J., and Winkler, P.: Increasing ozone over the atlantic ocean, Science, 304, 1483, doi:10.1126/science.1096777, 2004.

Logan, J. A.: Trends in the vertical distribution of ozone: An analysis of ozonesonde data, J. Geophys. Res., 99, 25553-25585, doi:10.1029/94JD02333, 1994.

Logan, J. A.: An analysis of ozonesonde data for the troposphere: Recommendations for testing 3-D models and development of a gridded climatology for tropospheric ozone, J. Geophys. Res., 104, 16115-16149, doi:10.1029/1998JD100096, 1999.

Logan, J. A. et al.: Changes in ozone over Europe: Analysis of ozone measurements from sondes, regular aircraft (MOZAIC) and alpine surface sites, J. Geophys. Res., doi:10.1029/2011JD016952, in press, 2012.

Marenco, A., Gouget, H., Nédélec, P., Pagés, J., and Karcher, F.: Evidence of a long-term increase in tropospheric ozone from pic du midi data series: Consequences: Positive radiative forcing, J. Geophys. Res., 99, 16617-16632, 1994.

Marenco, A., Thouret, V., Nedelec, P., Smit, H., Helten, M., Kley, D., Karcher, F., Simon, P., Law, K., Pyle, J., Poschmann, G., Von Wrede, R., Hume, C., and Cook, T.: Measurement of ozone and water vapor by Airbus in-service aircraft: The MOZAIC airborne program, an overview, J. Geophys. Res., 103, 2563125642, doi:10.1029/98JD00977, 1998.

McLinden, C. A., Olsen, S. C., Hannegan, B., Wild, O., Prather, M. J., and Sundet, J.: Stratospheric ozone in 3-D models: A simple chemistry and the cross-tropopause flux, J. Geophys. Res., 105, 14653-14665, doi:10.1029/2000JD900124, 2000.

Oltmans, S. J., Lefohn, A. S., Scheel, H. E., Harris, J. M., Levy II., H., Galbally, I. E., Brunke, E., Meyer, C. P., Lathrop, J. A., Johnson, B. J., Shadwick, D. S., Cuevas, E., Schmidlin, F. J., Tarasick, D. W., Claude, H., Kerr, J. B., Uchino, O., and Mohnen, V.: Trends of ozone in the troposphere, Geophys. Res. Lett., 25, 139-142, doi:10.1029/97GL03505, 1998.

Oltmans, S. J., Lefohn, A. S., Harris, J. M., Galbally, I., Scheel, H. E., Bodeker, G., Brunke, E., Claude, H., Tarasick, D., Johnson, B. J., Simmonds, P., Shadwick, D., Anlauf, K., Hayden, K., Schmidlin, F., Fujimoto, T., Akagi, K., Meyer, C., Nichol, S., Davies, J., Redondas, A., and Cuevas, E.: Long-term changes in tropospheric ozone, Atmos. Environ., 40, 3156-3173, 2006.

Ordoñez, C., Brunner, D., Staehelin, J., Hadjinicolaou, P., Pyle, J. A., Jonas, M., Wernli, H., and Prevot, A. S. H.: Strong influence of lowermost stratospheric ozone on lower tropospheric background ozone changes over Europe, Geophys. Res. Lett., 34, L07805, doi:10.1029/2006GL029113, 2007.

Parrish, D. D., Dunlea, E. J., Atlas, E. L., Schauffler, S., Donnelly, S., Stroud, V., Goldstein, A. H., Millet, D. B., McKay, M., Jaffe, D. A., Price, H. U., Hess, P. G., Flocke, F., and Roberts, J. M.: Changes in the photochemical environment of the temperate north pacific troposphere in response to increased Asian emissions, J. Geophys. Res., 109, D23S18, doi:10.1029/2004JD004978, 2004.

Parrish, D. D., Millet, D. B., and Goldstein, A. H.: Increasing ozone in marine boundary layer inflow at the west coasts of North America and Europe, Atmos. Chem. Phys., 9, 1303-1323, doi:10.5194/acp-9-1303-2009, 2009.

Price, C. and Rind, D.: A simple lightning parameterization for calculating global lightning distributions, J. Geophys. Res., 97, 9919-9933, doi:10.1029/92JD00719, 1992.

Pozzoli, L., Janssens-Maenhout, G., Diehl, T., Bey, I., Schultz, M. G., Feichter, J., Vignati, E., and Dentener, F.: Re-analysis of tropospheric sulfate aerosol and ozone for the period 1980-2005 using the aerosol-chemistry-climate model ECHAM5-HAMMOZ, Atmos. Chem. Phys., 11, 9563-9594, doi:10.5194/acp-11-95632011, 2011.

Randel, W. J., Wu, F., and Gaffen, D. J.: Interannual variability of the tropical tropopause derived from radiosonde data 
and NCEP reanalyses, J. Geophys. Res., 105, 15509-15523, doi:10.1029/2000JD900155, 2000.

Reidmiller, D. R., Fiore, A. M., Jaffe, D. A., Bergmann, D., Cuvelier, C., Dentener, F. J., Duncan, B. N., Folberth, G., Gauss, M., Gong, S., Hess, P., Jonson, J. E., Keating, T., Lupu, A., Marmer, E., Park, R., Schultz, M. G., Shindell, D. T., Szopa, S., Vivanco, M. G., Wild, O., and Zuber, A.: The influence of foreign vs. North American emissions on surface ozone in the US, Atmos. Chem. Phys., 9, 5027-5042, doi:10.5194/acp-9-5027-2009, 2009.

Roelofs, G. J. and Lelieveld, J.: Model study of the influence of cross tropopause $\mathrm{O}_{3}$ transports on tropospheric $\mathrm{O}_{3}$ levels, Tellus B, 49, 38-55, 1997.

Sanderson, M. G., Dentener, F. J., Fiore, A. M., Cuvelier, C., Keating, T. J., Zuber, A., Atherton, C. S., Bergmann, D. J., Diehl, T., and Doherty, R. M.: A multi-model study of the hemispheric transport and deposition of oxidised nitrogen, Geophys. Res. Lett., 35, L17815, doi:10.1029/2008GL035389, 2008.

Saunois, M., Emmons, L., Lamarque, J.-F., Tilmes, S., Wespes, C., Thouret, V., and Schultz, M.: Impact of sampling frequency in the analysis of tropospheric ozone observations, Atmos. Chem. Phys., 12, 6757-6773, doi:10.5194/acp-12-6757-2012, 2012.

Schnadt Poberaj, C., Staehelin, J., Brunner, D., Thouret, V., De Backer, H., and Stübi, R.: Long-term changes in UT/LS ozone between the late 1970s and the 1990s deduced from the GASP and MOZAIC aircraft programs and from ozonesondes, Atmos. Chem. Phys., 9, 5343-5369, doi:10.5194/acp-9-5343-2009, 2009.

Seidel, D. J. and Randel, W. J.: Variability and trends in the global tropopause estimated from radiosonde data, J. Geophys. Res., 111, D21101, doi:10.1029/2006JD007363, 2006.

Shepherd, T. G.: Dynamics, stratospheric ozone, and climate change, Atmos.-Ocean, 46, 117-138, 2008.

Shindell, D. T., Faluvegi, G., Unger, N., Aguilar, E., Schmidt, G. A., Koch, D. M., Bauer, S. E., and Miller, R. L.: Simulations of preindustrial, present-day, and 2100 conditions in the NASA GISS composition and climate model G-PUCCINI, Atmos. Chem. Phys., 6, 4427-4459, doi:10.5194/acp-6-4427-2006, 2006.

Shindell, D. T., Chin, M., Dentener, F., Doherty, R. M., Faluvegi, G., Fiore, A. M., Hess, P., Koch, D. M., MacKenzie, I. A., Sanderson, M. G., Schultz, M. G., Schulz, M., Stevenson, D. S., Teich, H., Textor, C., Wild, O., Bergmann, D. J., Bey, I., Bian, H., Cuvelier, C., Duncan, B. N., Folberth, G., Horowitz, L. W., Jonson, J., Kaminski, J. W., Marmer, E., Park, R., Pringle, K. J., Schroeder, S., Szopa, S., Takemura, T., Zeng, G., Keating, T. J., and Zuber, A.: A multi-model assessment of pollution transport to the Arctic, Atmos. Chem. Phys., 8, 5353-5372, doi:10.5194/acp-85353-2008, 2008.

Simmonds, P. G., Derwent, R. G., Manning, A. L., and Spain, G.: Significant growth in surface ozone at mace head, ireland, 19872003, Atmos. Environ., 38, 4769-4778, 2004.

Sitch, S., Cox, P. M., Collins, W. J., and Huntingford, C.: Indirect radiative forcing of climate change through ozone effects on the land-carbon sink, Nature, 448, 791-794, doi:10.1038/nature06059, 2007.

SPARC: Assessment of trends in the vertical distribution of ozone may 1988, SPARC Report No. 1, WMO Ozone Research and Monitoring Project Report No. 43, edited by: Harris, N., Hudson,
R., and Phillips, C., 1988.

Stevenson, D. S., Dentener, F. J., Schultz, M. G., Ellingsen, K., Van Noije, T. P. C., Wild, O., Zeng, G., Amann, M., Atherton, C. S., Bell, N., Bergmann, D. J., Bey, I., Butler, T., Cofala, J., Collins, W. J., Derwent, R. G., Doherty, R. M., Drevet, J., Eskes, H. J., Fiore, A. M., Gauss, M., Hauglustaine, D. A., Horowitz, L. W., Isaksen, I. S. A., Krol, M. C., Lamarque, J., Lawrence, M. G., Montanaro, V., Mueller, J., Pitari, G., Prather, M. J., Pyle, J. A., Rast, S., Rodriguez, J. M., Sanderson, M. G., Savage, N. H., Shindell, D. T., Strahan, S. E., Sudo, K., and Szopa, S.: Multimodel ensemble simulations of present-day and near-future tropospheric ozone, J. Geophys. Res., 111, D08301, doi:10.1029/2005JD006338, 2006.

Stübi, R., Levrat, G., Hoegger, B., Viatte, P., Staehelin, J., and Schmidlin, F. J.: In-flight comparison of Brewer-Mast and electrochemical concentration cell ozonesondes, J. Geophys. Res., 113, D13302 doi:10.1029/2007JD009091, 2008.

Tarasick, D. W., Fioletov, V. E., Wardle, D. I., Kerr, J. B., and Davies, J.: Changes in the vertical distribution of ozone over canada from ozonesondes: 1980-2001, J. Geophys. Res., 110, D02304, doi:10.1029/2004JD004643, 2005.

Terao, Y., Logan, J. A., Douglass, A. R., and Stolarski, R. S.: Contribution of stratospheric ozone to the interannual variability of tropospheric ozone in the northern extratropics, J. Geophys. Res., 113, D18309, doi:10.1029/2008JD009854, 2008.

Thouret, V., Cammas, J.-P., Sauvage, B., Athier, G., Zbinden, R., Nédélec, P., Simon, P., and Karcher, F.: Tropopause referenced ozone climatology and inter-annual variability (1994-2003) from the MOZAIC programme, Atmos. Chem. Phys., 6, 1033-1051, doi:10.5194/acp-6-1033-2006, 2006.

Tie, $\mathrm{X}$. and Hess, P.: Ozone mass exchange between the stratosphere and troposphere for background and volcanic sulfate aerosol conditions, J. Geophys. Res., 102, 25487-25500, 1997.

Trenberth, K. E., Fasullo, J., and Smith, L.: Trends and variability in column-integrated atmospheric water vapor, Clim. Dynam., 24, 741-758, doi:10.1007/s00382-005-0017-4, 2005.

UNCEC: Hemispheric transport of air pollution 2007, 146 pp., 2007.

UNEP: Environmental effects of ozone depletion and its interactions with climate change: 2006 assessment, 2006.

Van Dingenen, R., Dentener, F. J., Raes, F., Krol, M. C., Emberson, L., and Cofala, J.: The global impact of ozone on agricultural crop yields under current and future air quality legislation, Atmos. Environ., 43, 605-618, 2009.

Volz, A. and Kley, D.: Evaluation of the Montsouris series of ozone measurements made in the nineteenth century, Nature, 332, 240 242, doi:10.1038/332240a0, 1988.

Voulgarakis, A., Hadjinicolaou, P., and Pyle, J. A.: Increases in global tropospheric ozone following an el niño event: Examining stratospheric ozone variability as a potential driver, Atmos. Sci. Lett., 12, 228-232, doi:10.1002/asl.318, 2011.

Wang, Y., Jacob, D. J., and Logan, J. A.: Global simulation of tropospheric $\mathrm{O}_{3}-\mathrm{NO}_{\mathrm{x}}$-hydrocarbon chemistry, 3. Origin of tropospheric ozone and effects of nonmethane hydrocarbons, J. Geophys. Res., 103, 10757-10767, 1998.

West, J. J., Fiore, A. M., Naik, V., Horowitz, L. W., Schwarzkopf, M. D., and Mauzerall, D. L.: Ozone air quality and radiative forcing consequences of changes in ozone precursor emissions, Geophys. Res. Lett., 34, L06806, doi:10.1029/2006GL029173, 2007. 
Wilson, R. C., Fleming, Z. L., Monks, P. S., Clain, G., Henne, S., Konovalov, I. B., Szopa, S., and Menut, L.: Have primary emission reduction measures reduced ozone across Europe? An analysis of European rural background ozone trends 1996-2005, Atmos. Chem. Phys., 12, 437-454, doi:10.5194/acp-12-437-2012, 2012.

WMO (World Meteorological Organization): Scientific assessment of ozone depletion: 2002: Global ozone research and monitoring project - report no. 47, 498 pp., 2003.

Zbinden, R. M., Cammas, J.-P., Thouret, V., Nédélec, P., Karcher, F., and Simon, P.: Mid-latitude tropospheric ozone columns from the MOZAIC program: climatology and interannual variability, Atmos. Chem. Phys., 6, 1053-1073, doi:10.5194/acp-6-1053-2006, 2006.
Zeng, G. and Pyle, J. A.: Changes in tropospheric ozone between 2000 and 2100 modeled in a chemistry-climate model, Geophys. Res. Lett., 30, 1392, doi:10.1029/2002GL016708, 2003.

Zeng, G. and Pyle, J. A.: Influence of el nino southern oscillation on stratosphere/troposphere exchange and the global tropospheric ozone budget, Geophys. Res. Lett., 32, L01814, doi:10.1029/2004GL021353, 2005. 